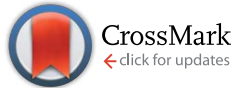

Cite this: RSC Adv., 2017, 7, 12236

Received 1st November 2016 Accepted 17th January 2017

DOI: $10.1039 / \mathrm{c} 6 \mathrm{ra} 26114 \mathrm{k}$

www.rsc.org/advances

\section{Influence of denticity and combined soft-hard strategy on the interaction of picolinic-type ligands with $\mathrm{NpO}_{2}{ }^{+} \dagger$}

\author{
Hongcai Ling, ${ }^{\text {ab }}$ Miaoren Xia, ${ }^{b}$ Wenkai Chen, ${ }^{\text {ac }}$ Zhifang Chai ${ }^{\text {bd }}$ and Dongqi Wang ${ }^{\text {*b }}$
}

The interaction of neptunyl ions $\left(\mathrm{NpO}_{2}^{+}\right)$with three picolinic type ligands $(\mathrm{L})$, including the deprotonated picolinic acid anion $\left(\mathrm{PA}^{-}\right)$, the deprotonated dipicolinic acid anion $\left(\mathrm{DPA}^{2-}\right)$ and the 1,10-phenanthroline2,9-dicarboxylic acid anion (PADA ${ }^{2-}$ ), was investigated by using a density functional theory method with various stoichiometric ratios of $N p: L=1: 1,1: 2$, and $1: 3$. The coordination modes, the influence of the denticity of the ligands, and the stoichiometry of the complexes were evaluated in terms of geometry, electronic structure, and thermodynamics. The calculations show that the coordination of $\mathrm{NpO}_{2}{ }^{+}$to tetradentate ligands is more stable than that to tridentate and bidentate ones, and the coordination ability of the three deprotonated ligands follows the order: $\mathrm{PADA}^{2-}>\mathrm{DPA}^{2-}>\mathrm{PA}^{-}$. Quantum theory of atoms-in-molecules (QTAIM) analysis, charge decomposition analysis (CDA) and natural atomic orbital (NAO) analysis were used to understand the bonding nature and electronic properties of the complexes, and the metal-ligand dative bond was identified to be mainly ionic. In view of the favorable coordination modes and the distinct ability of the ligands in binding to neptunyl, we conclude that the denticity of the ligands and the combined hard-soft donor strategy work cooperatively in the coordination of $\mathrm{NpO}_{2}{ }^{+}$with ligands. This work is expected to contribute to the rational design of new types of ligand with enhanced ability to extract neptunyl.

\section{Introduction}

As one of the minor actinides (neptunium, americium, and curium) in spent nuclear fuel (SNF), ${ }^{1-3}$ neptunium (Np) is considered to be one of the major issues in nuclear waste management owing to its high radioactivity and long halflifetime. Np has an electronic configuration of $[\mathrm{Rn}] 5 \mathrm{f}^{5} 7 \mathrm{~s}^{2}$ (or $\left.[\mathrm{Rn}] 5 \mathrm{f}^{4} 6 \mathrm{~d}^{1} 7 \mathrm{~s}^{2}\right)$ with multiple known oxidation states, i.e. III, IV, V, VI and VII, among which the most stable one in aqueous solutions is the penta-valent state, ${ }^{4,5}$ and predominantly exists as neptunyl cations $\left(\mathrm{NpO}_{2}{ }^{+}\right)$. The $\mathrm{NpO}_{2}^{+}$ion does not form strong complexes with the commonly used ligands and is hard to extract during spent fuel reprocessing. In the development of advanced SNF reprocessing protocols, the efficient separation of $\mathrm{Np}$ remains a challenge, and calls for extensive study, from

${ }^{a}$ College of Chemistry, Fuzhou University, Fuzhou 350116, P. R. China. E-mail: qc2008@fzu.edu.cn

${ }^{b}$ Multidisciplinary Initiative Center, Institute of High Energy Physics, Chinese Academy of Sciences, Beijing 100049, P. R. China.E-mail:dwang@ihep.ac.cn

${ }^{c}$ Key Laboratory of Applied Nuclear Techniques in Geosciences Sichuan, Chengdu University of Technology, Chengdu 610059, P. R. China

${ }^{d}$ School of Radiation Medicine and Interdisciplinary Sciences (RAD-X), Soochow University, Suzhou 215123, P. R. China

$\dagger$ Electronic supplementary information (ESI) available. See DOI: 10.1039/c6ra26114k both the experimental and theoretical sides, to shed light on the chemical behavior of $\mathrm{Np}$ in the condensed phase. ${ }^{6-11}$

In spent nuclear fuel reprocessing using extraction techniques, extractants containing heterocyclic $\mathrm{N}$ donors are attractive owing to their compositions of only $\mathrm{C}, \mathrm{H}, \mathrm{O}$ and $\mathrm{N}$, thus being completely incinerable to avoid secondary waste in nuclear waste treatment. The $\mathrm{N}$ donor ligands developed in recent years, such as bis(triazinyl)pyridines (BTPs), ${ }^{12,13}$ bis(triazinyl) bipyridines (BTBPs), ${ }^{\mathbf{1 4 - 1 6}}$ bis(triazinyl)-1,10-phenanthrolines (BTPhens), ${ }^{\text {,17-19 }}$ have been considered as promising extractants for minor actinides. These earlier studies mainly focused on the efficient separation of trivalent lanthanides and actinides, and neptunyl was rarely considered due to its weak extractability by organic ligands.

In recent years, Rao et al..$^{\mathbf{2 0 - 2 6}}$ and other groups ${ }^{27,28}$ conducted a series of experimental studies to evaluate the performance of ligands containing $\mathrm{O}$ and $\mathrm{N}$ in their binding with neptunyl. These cover the determination of the thermodynamic parameters (stability constants, enthalpy, and entropy) by spectrophotometry and microcalorimetry, and X-ray crystallographic studies of neptunyl complexes with dicarboxylic acids as well as the diamide derivatives, such as oxydiacetic acid (ODA), $N, N$-dimethyl-3-oxa-glutaramic acid (DMOGA) and, $N, N, N^{\prime}, N^{\prime}$ tetramethyl-3-oxa-glutaramide (TMOGA), and 1,10phenanthrolin-2,9-dicarboxylic acid ( $\left.\mathrm{H}_{2} \mathrm{PADA}\right)$. In their recent work of $\mathrm{H}_{2} \mathrm{PADA}$, Rao et al. compared ${ }^{25}$ it with picolinic acid (HPA $)^{29}$ and dipicolinic acid $\left(\mathrm{H}_{2} \mathrm{DPA}\right),{ }^{23}$ and found 
that the complexation of neptunyl ions with the tetradentate $\mathrm{H}_{2}$ PADA ligand is much stronger than with other ligands (HPA and $\mathrm{H}_{2} \mathrm{DPA}$ ), and proposed that it could be an excellent extractant in the separation of neptunyl ions. Note that, both $\mathrm{H}_{2}$ DPA and $\mathrm{H}_{2}$ PADA, comparing to some other $\kappa^{3}$ and $\kappa^{4}$ chelating ligands, have preorganized planar structures with their donor atoms, i.e. $\mathrm{O}$ and $\mathrm{N}$, aligned on the same side to prepare for the coordination with neptunyl in the equatorial plane, thus save the energy cost that may be needed for the ligands with backbone dihedral freedoms. ${ }^{30}$

In earlier work, we have reported B3LYP studies on the coordination chemistry and thermodynamics of neptunyl with the ligands of $N, N, N^{\prime}, N^{\prime}$-tetramethyl-3-oxa-glutaramide (TMOGA), $N, N$-dimethyl-3-oxa-glutaramic acid (DMOGA), deprotonated oxydiacetic analog (ODA), and BTPs, BTBPs, BTPhens. ${ }^{9,31}$ which show that the denticity of the chelating ligands is key to their interaction with neptunyl. In this work, we extend our study and aim to understand the influence of denticity of ligands and the importance to consider the combined soft-hard donor strategy in developing new types of ligands to extract actinides. For this purpose, we investigated the complexation behavior of $\mathrm{NpO}_{2}{ }^{+}$ with $\mathrm{H}_{2}$ PADA and its two picolinic derivatives by using density functional theory method. The geometries of the complexes have been optimized, and the free energy change of ligand exchange processes have been calculated and analyzed to find the most probable coordination modes of each ligands. To understand the coordination modes and bonding nature of $\mathrm{NpO}_{2}^{+}$with these ligands, the quantum theory of atoms-in-molecules (QTAIM) topological analysis, charge decomposition analysis (CDA), and natural atomic orbital (NAO) analysis were carried to reveal the feature of the metal-ligand dative bonds. The results were compared to the experimental data to show that the computational work may complement experimental studies by providing molecular level of details.

\section{Methods}

The ligands in experimental studies, ${ }^{25} \mathrm{HPA}, \mathrm{H}_{2} \mathrm{DPA}$, and $\mathrm{H}_{2}$ PADA, as shown in Scheme 1, were used as the prototype models to investigate the complexation of neptunyl ion $\left(\mathrm{NpO}_{2}^{+}\right)$ with the deprotonated picolinic acid anion $\left(\mathrm{PA}^{-}\right)$, the

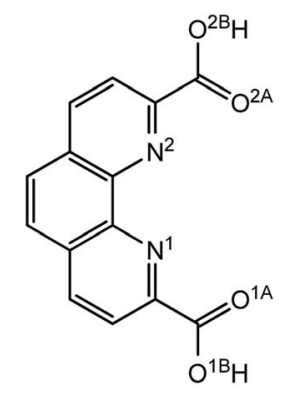

HPA

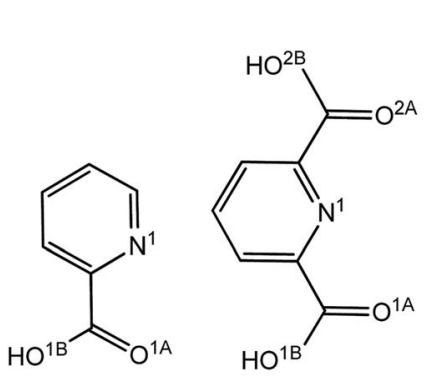

$\mathrm{H}_{2} \mathrm{DPA}$
$\mathrm{H}_{2} \mathrm{PADA}$
Scheme 1 Schematic elucidation of the three ligands discussed in this paper. deprotonated dipicolinic acid anion $\left(\mathrm{DPA}^{2-}\right)$, and the 1,10phenanthrolin-2,9-dicarboxylic acid anion $\left(\mathrm{PADA}^{2-}\right)$.

All geometry optimization and frequency calculations were carried out by using the B3LYP functional ${ }^{32-34}$ as implemented in the Gaussian 09 program..$^{35}$ Frequency analysis was done for all of the optimized stationary points to identify their nature as minima, and to obtain the thermodynamic parameters (enthalpy $(\Delta H)$, Gibbs free energy $(\Delta G)$, and entropy $(\Delta S)$ ), which were used to evaluate the thermodynamic feasibility of the binding process ${ }^{36,37}$ of hydrated neptunyl with the picolinic-type ligands. Two combined basis sets have been used differing in the treatment of $\mathrm{C}, \mathrm{H}, \mathrm{O}$ and $\mathrm{N}$, one with the $6-31+\mathrm{G}^{*}$ (ref. 38) basis set (BS1), which was used for geometry optimization and frequency calculations, and another one with the larger basis set 6-311++G(d,p) (BS2) to refine energies. ${ }^{39-41}$ In both basis sets, the $\mathrm{Np}$ atom was treated by a small-core quasi-relativistic effective core potentials (5f-in-valence RECPs) for the 60 core electrons, and the corresponding valence basis set adopted a contraction scheme of (14s13p10d8f6g)/[10s9p5d4f3g] (ECP60MWB basis) ${ }^{42-44}$ to describe the valence shells.

The solvent effect of water was taken into account with the polarizable continuum model (PCM). ${ }^{45,46}$ GaussView 5.0 program $^{47}$ was used for visualization of structures and molecular orbitals. The Multiwfn 3.2 program $^{48}$ was used to carry out the quantum theory of atoms-in-molecules (QTAIM) ${ }^{49-52}$ topological analysis to understand the coordination modes and bonding nature of complexes ${ }^{53}$ described by five parameters at the $(3,-1)$ bond critical point (BCP), i.e. the electron density at $\operatorname{BCP}\left(\rho_{\mathrm{b}}\right)$, the Laplacian of electron density at $\operatorname{BCP}\left(\nabla^{2} \rho_{\mathrm{b}}\right)$, the total energy density at $\mathrm{BCP}\left(H_{\mathrm{b}}\right)$, the delocalization index $(\delta(A, B))$, and the bond ellipticity $(\varepsilon)$. Charge decomposition analysis (CDA) and natural atomic orbital (NAO) analysis were also done to evaluate the ionic interaction in complex formation and the covalency of the metal-ligand dative bond.

\section{Results and discussion}

\section{A. Geometries and relative energies}

As shown in Scheme 1, the three ligands differ in their denticities when coordinating to metal ions, which are 2, 3, and 4 for $\mathrm{PA}^{-}, \mathrm{DPA}^{2-}$ and $\mathrm{PADA}^{2-}$, respectively. As all of the three ligands may interact with neptunyl with their carboxyl groups, it is also possible for them to coordinate with neptunyl in a $\eta^{1}$ (with one of the two $\mathrm{O}^{\text {carb }}$ atoms) or $\kappa^{2}$ (with both $\mathrm{O}^{\text {carb }}$ atoms) manner. Thus, in this work, we have done an exhaustive search of coordination modes that the neptunyl-ligand complexes may take. In these complexes, a coordination number (C.N.) of neptunyl in its equatorial plane as 5 or 6 is retained, and the excess coordination sites may be occupied by additional same ligand, either in the identical or distinct coordination modes, or water molecules. This results in 17,10 , and 4 possible complexes for $\mathrm{PA}^{-}, \mathrm{DPA}^{2-}$ and $\mathrm{PADA}^{2-}$, respectively. The representative stationary points with the lowest energy in each set of stoichiometric ratio from the calculations in the aqueous phase are shown in Fig. 1, and the rest complexes are collected in the ESI. $\dagger$ 


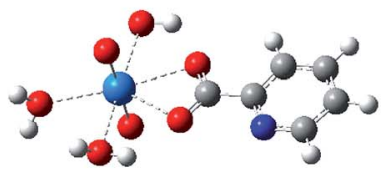

$\left[\mathrm{NpO}_{2}(\mathrm{PA})\left(\mathrm{H}_{2} \mathrm{O}\right)_{3}\right]_{-} \mathrm{C}$ (P1C)

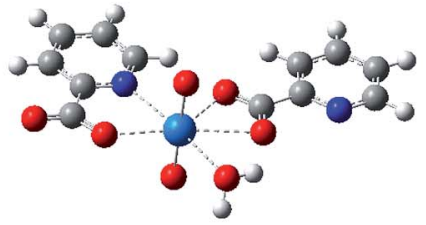

$\left[\mathrm{NpO}_{2}(\mathrm{PA})_{2}\left(\mathrm{H}_{2} \mathrm{O}\right)\right]^{-} \mathrm{C}_{-} \mathrm{N}$ (P2CN)

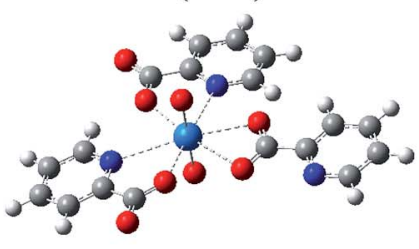

$\left[\mathrm{NpO}_{2}(\mathrm{PA})_{3}\right]^{2-}{ }_{-} \mathrm{C}_{-} \mathbf{N} \_\mathrm{N}$ (P3CNN)

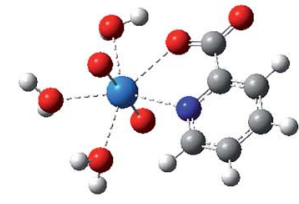

$\left[\mathrm{NpO}_{2}(\mathrm{PA})\left(\mathrm{H}_{2} \mathrm{O}\right)_{3}\right]_{-} \mathrm{N}$ (P1N)

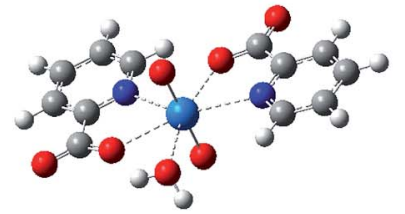

$\left[\mathrm{NpO}_{2}(\mathrm{PA})_{2}\left(\mathrm{H}_{2} \mathrm{O}\right)\right]^{-} \_\mathbf{N} \_\mathbf{N}$ (P2NN)

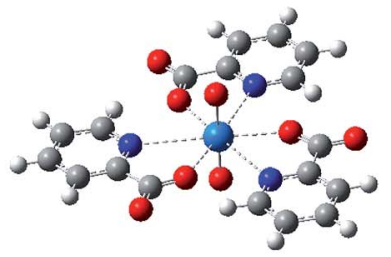

$\left[\mathrm{NpO}_{2}(\mathrm{PA})_{3}\right]^{2-}{ }_{-} \mathrm{N}_{-} \mathrm{N} \_\mathrm{N}$ (P3NNN)

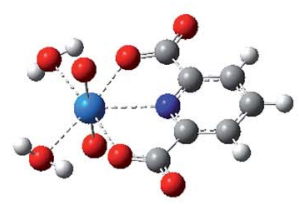

$\left[\mathrm{NpO}_{2}(\mathrm{DPA})\left(\mathrm{H}_{2} \mathrm{O}\right)_{2}\right]_{-}^{-} \mathrm{N}$

(D1N)

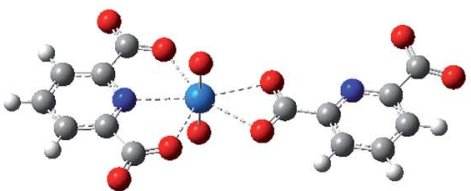

$\left[\mathrm{NpO}_{2}(\mathrm{DPA})_{2}\right]_{-}^{3-} \mathrm{C}_{-} \mathrm{N}$

(D2CN)

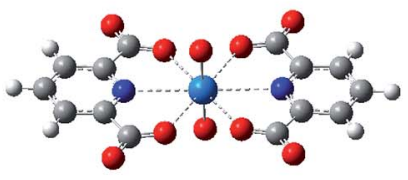

$\left[\mathrm{NpO}_{2}(\mathrm{DPA})_{2}\right]^{3-}{ }_{-} \mathrm{N} \_\mathrm{N}$

(D2NN)

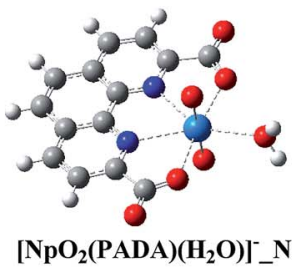

(H1W1)

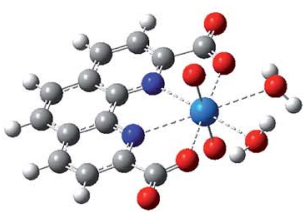

$\left[\mathrm{NpO}_{2}(\mathrm{PADA})\left(\mathrm{H}_{2} \mathrm{O}\right)_{2}\right]_{-}^{-} \mathbf{N}$ (H2W2)

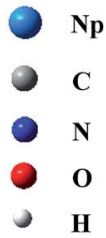

Fig. 1 Representative conformations of the complexes obtained at the B3LYP level in the aqueous phase. $\left(\mathrm{P} 1 \mathrm{C}\right.$ : $\left[\mathrm{NpO}{ }_{2}(\mathrm{PA})\left(\mathrm{H}_{2} \mathrm{O}\right)_{3}\right]_{-} \mathrm{C}$, $\mathrm{P} 1 \mathrm{~N}$ : $\left.\left[\mathrm{NpO}_{2}(\mathrm{PA})\left(\mathrm{H}_{2} \mathrm{O}\right)_{3}\right]_{-} \mathrm{N}, \mathrm{P} 2 \mathrm{CN}:\left[\mathrm{NpO}_{2}(\mathrm{PA})_{2}\left(\mathrm{H}_{2} \mathrm{O}\right)\right]^{-} \_\mathrm{C} \_\mathrm{N}, \mathrm{P} 2 \mathrm{NN}:\left[\mathrm{NpO}_{2}(\mathrm{PA})_{2}\left(\mathrm{H}_{2} \mathrm{O}\right)\right]^{-} \_\mathrm{N} \_\mathrm{N}, \mathrm{P} 3 \mathrm{CNN}:[\mathrm{NpO})_{2}(\mathrm{PA})_{3}\right]^{2-}{ }_{-} \mathrm{C} \_\mathrm{N} \_\mathrm{N}, \mathrm{P} 3 \mathrm{NNN}:[\mathrm{NpO})_{2}(-$ $\left.\mathrm{PA})_{3}\right]^{2-} \_\mathrm{N} \_\mathrm{N} \_\mathrm{N}, \mathrm{D} 1 \mathrm{~N}:\left[\mathrm{NpO}_{2}\left(\kappa^{3}-\mathrm{DPA}\right)\left(\mathrm{H}_{2} \mathrm{O}\right)_{2}\right]^{-} \_\mathrm{N}, \mathrm{D} 2 \mathrm{CN}:\left[\mathrm{NpO}_{2}\left(\kappa^{3}-\mathrm{DPA}\right)\left(\kappa^{2}-\mathrm{DPA}\right)\right]^{3-}{ }_{-} \mathrm{C} \_\mathrm{N}, \mathrm{D} 2 \mathrm{NN}:\left[\mathrm{NpO}{ }_{2}\left(\kappa^{3}-\mathrm{DPA}\right)_{2}\right]^{3-}{ }_{-} \mathrm{N} \_\mathrm{N}, \mathrm{H} 1 \mathrm{~W} 1:\left[\mathrm{NpO} \mathrm{N}_{2}\left(\kappa^{4}-\right.\right.$ $\left.\left.\mathrm{PADA})\left(\mathrm{H}_{2} \mathrm{O}\right)\right]^{-} \_\mathrm{N}, \mathrm{H} 2 \mathrm{~W} 2:\left[\mathrm{NpO}_{2}\left(\kappa^{4}-\mathrm{PADA}\right)\left(\mathrm{H}_{2} \mathrm{O}\right)_{2}\right]^{-} \_\mathrm{N}\right)$.

As a bidentate ligand, $\mathrm{PA}^{-}$may coordinate with neptunyl either in the manner of end-on with its carboxyl group (denoted as _C) or side-on with its $\mathrm{N}$ and one $\mathrm{O}^{1 \mathrm{~A}}$ of the carboxyl group (denoted as _N). In Fig. 1, six complexes of neptunyl-PA ${ }^{-}$are shown, differing in the coordination mode and the stoichiometric ratio, which is up to $\mathrm{Np}: \mathrm{PA}^{-}=1: 3$ with $\mathrm{Np}$ atom remaining penta- or hex-coordinated in its equatorial plane. In addition, in Fig. 1, three complexes of $\mathrm{DPA}^{2-}$, with one, two and two $\mathrm{DPA}^{2-}$ in the complex, respectively, and two of $\mathrm{PADA}^{2-}$ are also shown. In the complexes with $\mathrm{Np}: \mathrm{DPA}^{2-}=1: 2$, one $\mathrm{DPA}^{2-}$ appears as a tridentate ligand, and another one may coordinate with Np either in $\kappa^{2}(\mathbf{D} 2 \mathbf{C N})$ or $\kappa^{3}(\mathbf{D} 2 \mathbf{N N})$ manner. In the case of $\mathrm{PADA}^{2-}$, as the ligand binds with $\mathrm{Np}$ in $\kappa^{4}$ manner, and constitutes substantial steric hindrance to prevent the coappearance of additional $\mathrm{PADA}^{2-}$, here we only considered the stoichiometric ratio of $\mathrm{Np}: \mathrm{DAPA}^{2-}=1: 1$ (H1W1 and
H2W2, differing in the presence of one or two water molecules respectively).

The averaged bond lengths $d(\AA)$ of $\mathrm{Np}-\mathrm{O}^{\mathrm{yl}}, \mathrm{Np}-\mathrm{N}^{\mathrm{py}}, \mathrm{Np}-$ $\mathrm{O}^{\text {carb }}$, and $\mathrm{Np}-\mathrm{O}^{\text {wat }}$ bonds were summarized in Table 1 and ESI. $\dagger$ In bare neptunyl, the $\mathrm{Np}-\mathrm{O}^{\mathrm{yl}}$ bond distance is calculated to be 1.737 and $1.781 \AA$ in gas phase and in aqueous phase, respectively. This value increase to 1.780 and $1.794 \AA$ in its pentahydrated form (N1 in Table 1), which suggests that the coordination of water ligands to neptunyl in its equatorial plane weakens the $\mathrm{Np}-\mathrm{O}^{\mathrm{yl}}$ bonds. Upon its coordination to the three negatively charged organic ligands, the $\mathrm{Np}-\mathrm{O}^{\mathrm{yl}}$ bond is perturbed and elongated to 1.81-1.83 $\AA$, suggesting a stronger perturbation brought by these ligands than by water.

We also note that for the dative bonds in the complexes, in general the bond length of $\mathrm{Np}-\mathrm{O}^{\text {carb }}$ is about $0.1-0.2 \AA$ shorter than that of $\mathrm{Np}-\mathrm{N}^{\mathrm{Py}}$ and $\mathrm{Np}-\mathrm{O}^{\text {wat }}$ bonds. This may be

Table 1 The averaged bond lengths $(\AA)$ of $\mathrm{Np}-\mathrm{O}^{\mathrm{yl}}, \mathrm{Np}-\mathrm{N}^{\mathrm{py}}, \mathrm{Np}-\mathrm{O}^{\text {carb }}$, and $\mathrm{Np}-\mathrm{O}^{\text {water }}$ in the complexes calculated in the aqueous phase

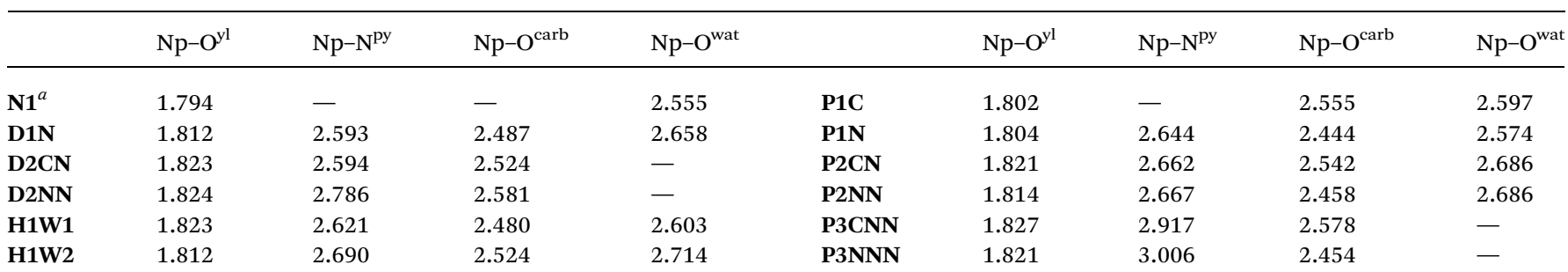

${ }^{a} \mathbf{N 1 :}\left[\mathrm{NpO}_{2}\left(\mathrm{H}_{2} \mathrm{O}\right)_{5}\right]^{+}$. 
determined by the stronger electrostatic interaction between $\mathrm{Np}$ and $\mathrm{O}^{\text {carb }}$ than between $\mathrm{Np}$ and the other two types of coordinating atoms.

In aqueous phase, neptunyl exists in its hydrated form with five water molecules bound in the first coordination shell. Starting from $\left[\mathrm{NpO}_{2}\left(\mathrm{H}_{2} \mathrm{O}\right)_{5}\right]^{+}$, the thermodynamics of the formation of the above-mentioned complexes was evaluated via ligand exchange process to replace the water ligands by corresponding organic ligands. The data are collected in Table 2. $23,25,29$

In Table 2, the eqn (1) to (6) were used to calculate the thermodynamics for the formation of the neptunyl-PA complexes with the stoichiometric ratio of $\mathrm{Np}: \mathrm{L}$ varies from $1: 1$ to $1: 2$ to $1: 3$. It can be seen that the $\mathrm{NpL}_{2}(\mathbf{P 2 C N}$ and P2NN) complexes is thermodynamically more stable than NpL (P1C and P1N) and comparable with $\mathrm{NpL}_{3}$ (P3CNN and P3NNN) both in the gas phase (data in $\mathrm{ESI}^{\dagger}$ ) and in water, suggesting that neptunyl has stronger affinity to $\mathrm{PA}^{-}$than to water ligand, but with an optimal stoichiometric ratio of $1: 2$. Regarding to the coordination mode, with one $\mathrm{PA}^{-}$bound, neptunyl favors the _ $\mathrm{N}$ mode to benefit from both the excess negative charge of the carboxyl group (P1C: $\mathrm{C}-\mathrm{O}^{1 \mathrm{~A}}=1.269 \AA, \mathrm{C}-\mathrm{O}^{1 \mathrm{~B}}=1.273 \AA$ vs. P1N: $\mathrm{C}-\mathrm{O}^{1 \mathrm{~A}}=1.286 \AA$, $\mathrm{C}-\mathrm{O}^{1 \mathrm{~B}}=1.242 \AA$ ) and pyridine $\mathrm{N}$ atom which is relatively "softer" than the carbonyl $\mathrm{O}^{1 \mathrm{~B}}$ atom according to Pierson's Hard-Soft-Acid-Base (HSAB) principle. ${ }^{54,55}$ This rule holds with one or two more $\mathrm{PA}^{-}$bound, and neptunyl does not favor to bind with all of the $\mathrm{PA}^{-}$ligands in the _N mode, but rather with one $\mathrm{PA}^{-}$in the _C mode and the rest in the _N mode.
The $\mathrm{DPA}^{2-}$ ligand behaves similarly to $\mathrm{PA}^{-}$, and in the $1: 1$ complex, it binds with neptunyl in the $\kappa^{3}\left(\_N\right)$ mode rather than the $\kappa^{2}$ (_C) mode. The presence of one more $\mathrm{DPA}^{2-}$ ligand brings additional stabilization energy to the complexes, with the $\kappa^{3}$ mode $\left(-53.32 \mathrm{kcal} \mathrm{mol}^{-1}\right)$ moderately more favorable than the $\kappa^{2}$ mode $\left(-51.41 \mathrm{kcal} \mathrm{mol}^{-1}\right)$.

The PADA $^{2-}$ ligand displays exceptional binding affinity to neptunyl and the substitution of four water ligands by one $\mathrm{PADA}^{2-}$ is calculated to be exothermic by $55.10 \mathrm{kcal} \mathrm{mol}^{-1}$. This suggests that at the same stoichiometric ratio, $\mathrm{PADA}^{2-}$ is superior over the other two ligands toward to the coordination with neptunyl. This trend is consistent with the experimental observations ${ }^{23,25,29}$ as shown in Table 2.

In summary, the thermodynamic stability of the complexes of $\mathrm{NpO}_{2}{ }^{+}$with the three pyridine-based carboxylate ligands follow the order: $\mathrm{PADA}^{2-}\left(-55.1 \mathrm{kcal} \mathrm{mol}^{-1}\right)>\mathrm{DPA}^{2-}(-53.32$ kcal $\left.\mathrm{mol}^{-1}\right)>\mathrm{PA}^{-}\left(-41.24 \mathrm{kcal} \mathrm{mol}^{-1}\right)$ in the aqueous phase, suggesting that the phenanthroline-based tetradentate ligand $\left(\mathrm{PADA}^{2-}\right)$ has the best binding affinity with neptunyl than the other two ligands. The calculations also show that the binding mode with combined "hard-soft" donors brings more stabilization energy to the complexes than that with only "hard" donors. The former binding mode gains enthalpy without the loss of entropic contribution. This is reasonable concerning that the carboxylate group builds stronger hydrogen bonding with water solvent than the $\mathrm{N}^{\mathrm{py}}$ does, thus the _C binding mode requires more energy to reorganize solvent environment than the _ $\mathrm{N}$ mode does.

Table 2 The thermodynamics $\left(\mathrm{kcal} \mathrm{mol}^{-1}\right)$ of selected ligand exchange reactions towards the formation of the $\mathrm{NpO}_{2}{ }^{+}$complexes with the three ligands at $298.15 \mathrm{~K}$ in the aqueous phase

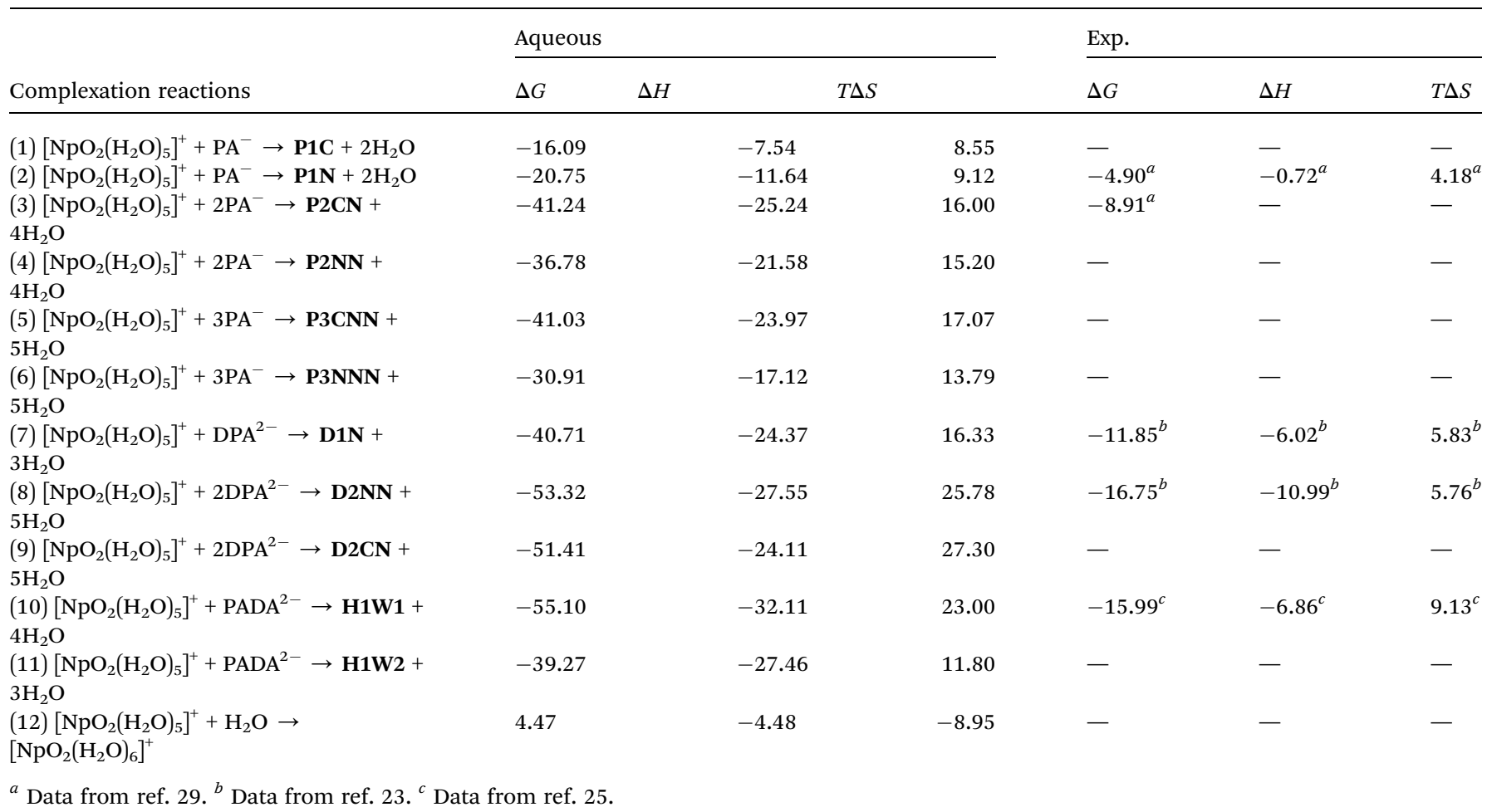




\section{B. QTAIM topological analysis}

The quantum theory of atoms-in-molecules (QTAIM) topological analysis of Bader ${ }^{49,52}$ and Matta and Boyd ${ }^{56}$ et al. were used to understand the bonding nature and electronic properties of the complexes. Five descriptors in the framework of AIM, i.e. the density $\rho_{\mathrm{b}}$ at the $(3,-1)$ bond critical point $(\mathrm{BCP})$, the Laplacian of electron density at $\mathrm{BCP}\left(\nabla^{2} \rho_{\mathrm{b}}\right)$, the total energy density at BCP
$\left(H_{\mathrm{b}}\right)$, the delocalization index $(\delta(A, B))$, and the bond ellipticity $(\varepsilon)$, were used to characterize the interactions between $\mathrm{Np}$ and ligands. The values of these descriptors are tabulated in Table 3 and ESI. $\dagger$

In a bare neptunyl ion (No), for the $\mathrm{Np}-\mathrm{O}^{\mathrm{yl}}$ bond, the electron density $\rho_{\mathrm{b}}$, the Laplacian of electron density $\left(\nabla^{2} \rho_{\mathrm{b}}\right)$, and the total energy density $\left(H_{\mathrm{b}}\right)$ at the $(3,-1)$ bond critical point $(\mathrm{BCP})$ were

Table 3 Electron density $\rho_{\mathrm{b}}\left(\mathrm{e}\right.$ bohr $\left.{ }^{-3}\right)$ and its Laplacian $\nabla^{2} \rho_{\mathrm{b}}\left(\mathrm{e}\right.$ bohr $\left.{ }^{-5}\right)$, the energy density $H_{\mathrm{b}}($ a.u. $)$ at the bond critical point, and the averaged delocalization indices $\bar{\delta}$ (a.u.) and averaged bond ellipticity $\bar{\varepsilon}$ (a.u.) of the $\mathrm{Np}-\mathrm{O}^{\mathrm{yl}}, \mathrm{Np}-\mathrm{N}^{\mathrm{py}}, \mathrm{Np}-\mathrm{O}^{\text {carb }}$, and $\mathrm{Np}-\mathrm{O}^{\text {water }}$ bonds of the complexes obtained from QTAIM analysis ( $\mathrm{NO}: \mathrm{NpO}_{2}{ }^{+}, \mathrm{N1}:\left[\mathrm{NpO}_{2}\left(\mathrm{H}_{2} \mathrm{O}\right)_{5}\right]^{+}$)

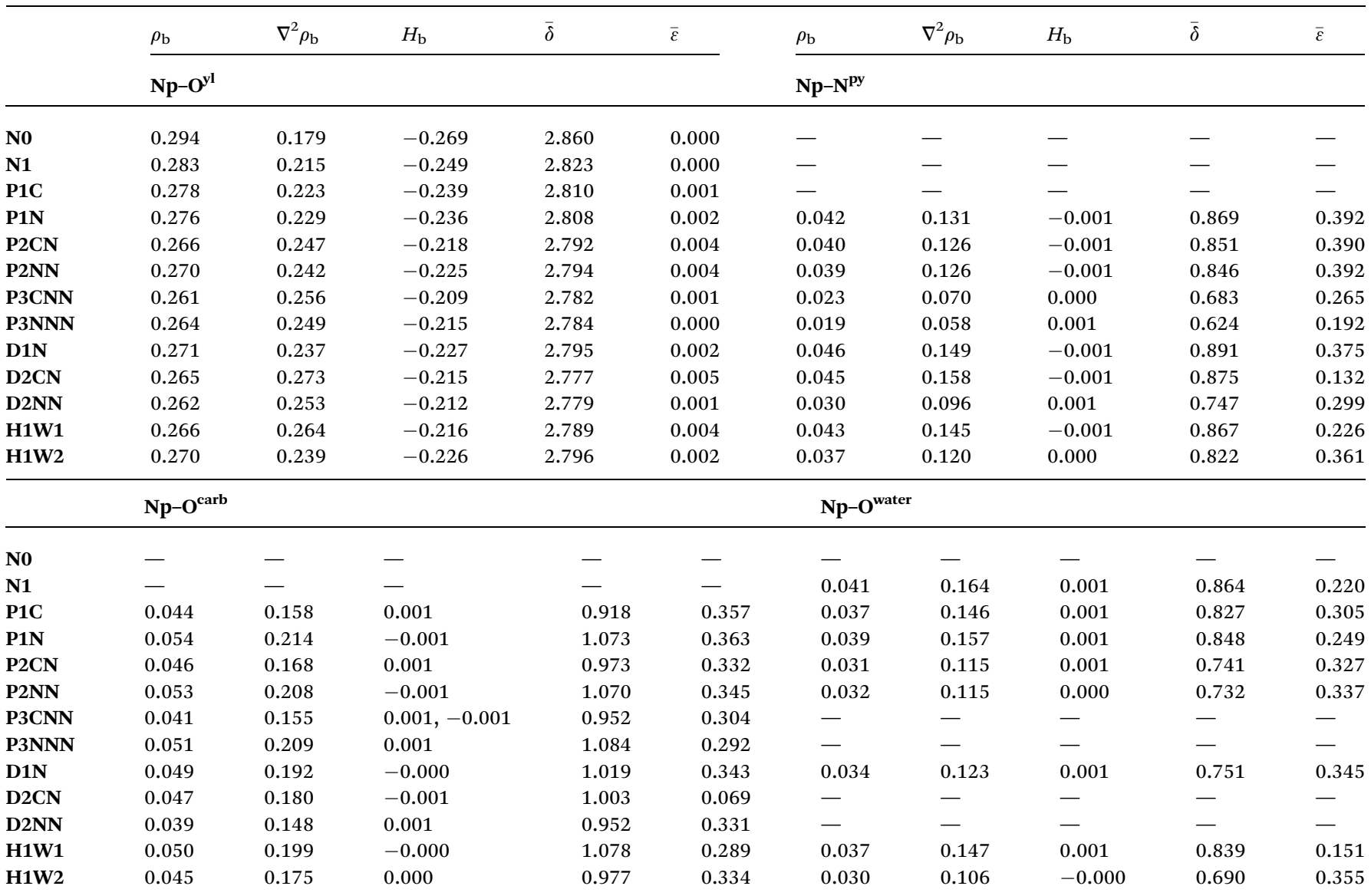
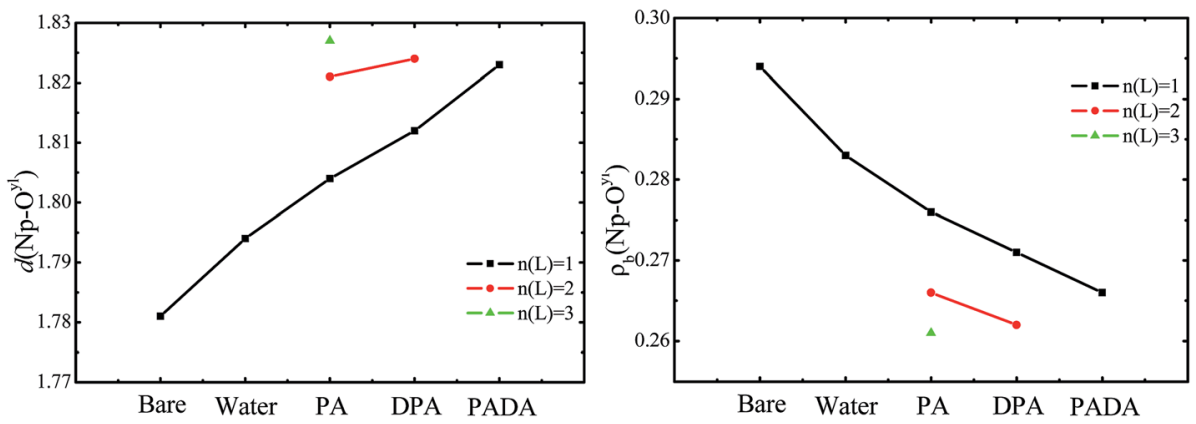

Fig. 2 The bond length $d(\AA)$, and the electron density $\rho_{\mathrm{b}}\left(\mathrm{e}^{-}\right.$bohr $\left.{ }^{-3}\right)$ at BCP of $\mathrm{Np}-\mathrm{O}^{\mathrm{yl}}$ bond in complexes from calculations in the aqueous phase. The values of $\mathrm{NpO}_{2}{ }^{+}$in its hydrated and bare forms are also shown for comparison (bare: $\mathrm{NpO}_{2}{ }^{+}, \mathrm{water}\left[\mathrm{NpO} \mathrm{O}_{2}\left(\mathrm{H}_{2} \mathrm{O}\right)_{5}\right]^{+}, \mathrm{PA}[n(\mathrm{~L})=1]$ : $\mathrm{P} 1 \mathrm{~N}$, $\mathrm{PA}[n(\mathrm{~L})=2]$ : P2CN, PA $[n(\mathrm{~L})=3]$ : P3CNN, DPA $[n(\mathrm{~L})=1]$ : D1N, DPA $[n(\mathrm{~L})=2]$ : D2NN, PADA $[n(\mathrm{~L})=1]$ : H1W1). 
$[0.335,0.120,-0.347]$ and $[0.294,0.179,-0.269]$ respectively in the gas phase and in the aqueous phase, $\rho_{\mathrm{b}}>0.20, \nabla^{2} \rho_{\mathrm{b}}>0, H_{\mathrm{b}}<$ 0 . According to Matta and Boyd, ${ }^{56} \mathrm{a} \rho_{\mathrm{b}}$ greater than $0.20 \mathrm{e}$ bohr ${ }^{-3}$, a positive $\nabla^{2} \rho_{\mathrm{b}}$, and a negative $H_{\mathrm{b}}$ are the feature of a shared bond. This means that the interactions between $\mathrm{Np}$ and $\mathrm{O}^{\mathrm{yl}}$ has strong covalent feature.

In contrast, the interaction between $\mathrm{Np}$ and the coordinating atoms, both for the $\mathrm{O}^{\text {carb }}$ and $\mathrm{N}^{\mathrm{py}}$, displays predominant ionic

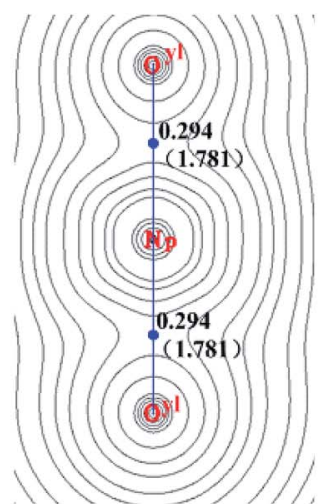

$\left[\mathrm{NpO}_{2}\right]^{+}$

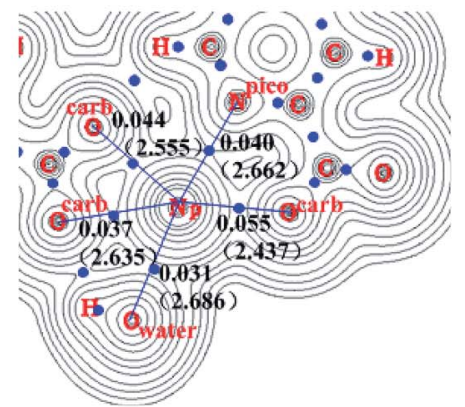

$\left[\mathrm{NpO}_{2}(\mathrm{PA})_{2}\left(\mathrm{H}_{2} \mathrm{O}\right)\right]^{-}{ }_{-} \mathrm{C} N \mathrm{~N}$
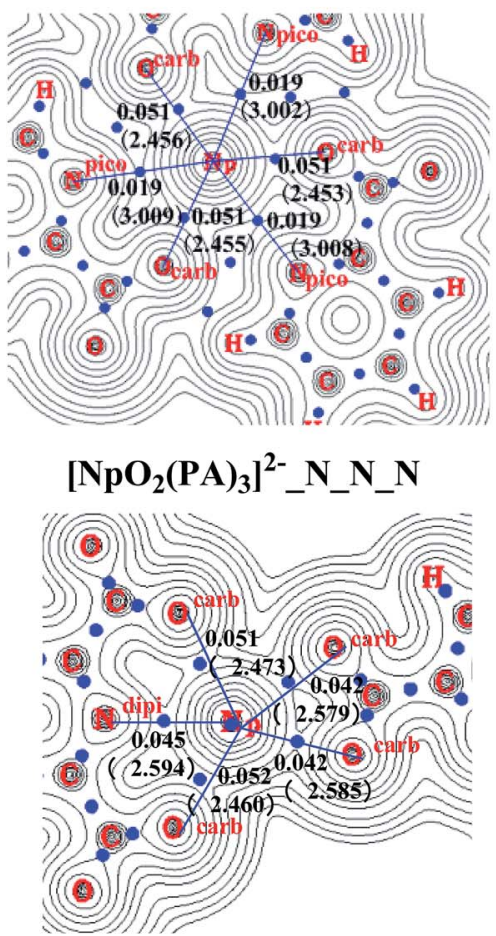

$\left[\mathrm{NpO}_{2}(\mathrm{DPA})_{2}\right]^{3-}{ }_{-} \mathrm{C}_{-} \mathbf{N}$

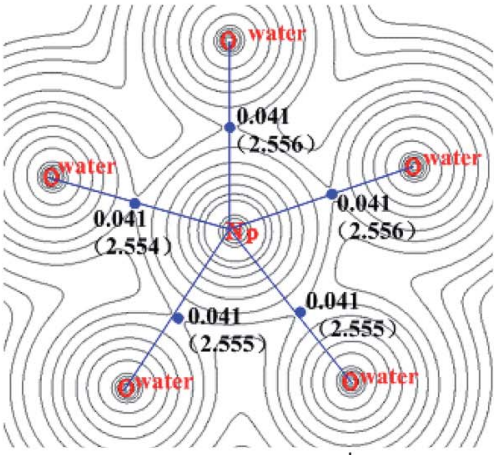

$\left[\mathrm{NpO}_{2}\left(\mathrm{H}_{2} \mathrm{O}\right)_{5}\right]^{+}$
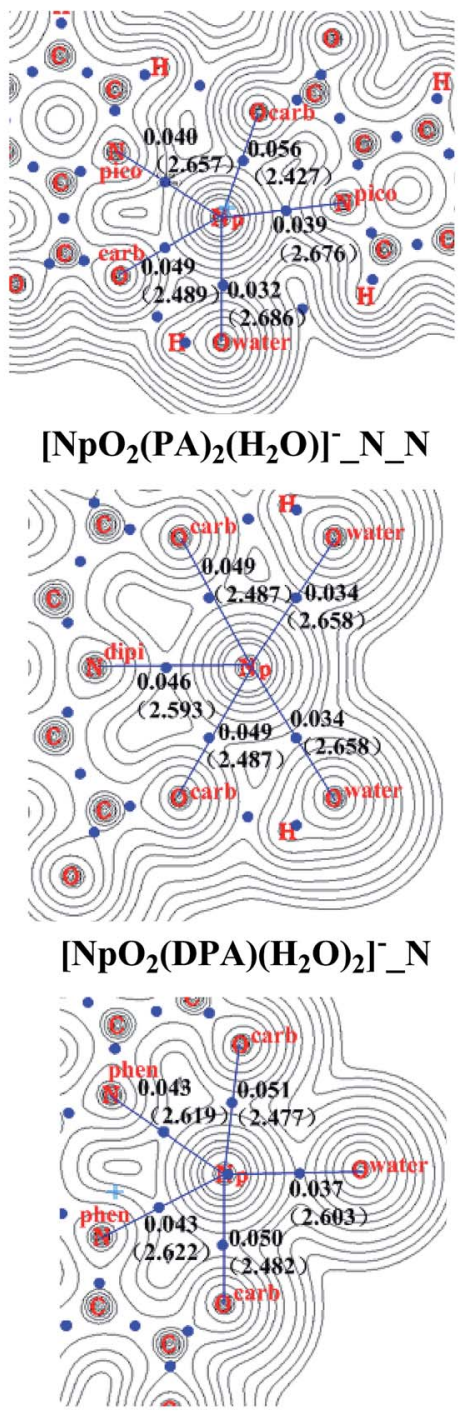

$\left[\mathrm{NpO}_{\mathbf{2}}(\mathrm{PADA})\left(\mathrm{H}_{2} \mathrm{O}\right)\right]^{-} \_\mathrm{N}$

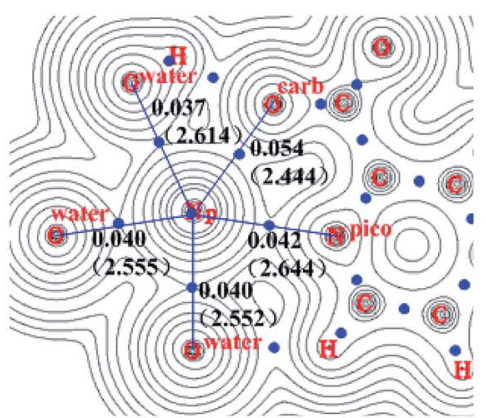

$\left[\mathrm{NpO}_{2}(\mathrm{PA})\left(\mathrm{H}_{2} \mathrm{O}\right)_{3}\right]_{-} \mathbf{N}$

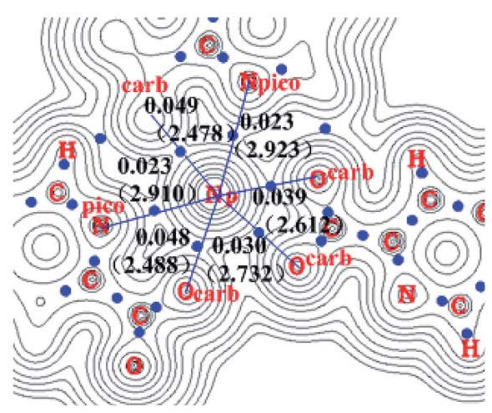

$\left[\mathrm{NpO}_{2}(\mathrm{PA})_{3}\right]^{2-} \mathrm{C}_{-} \mathbf{N} \_\mathrm{N}$

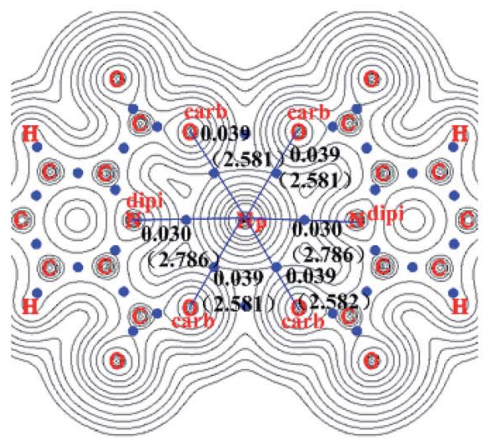

$\left[\mathrm{NpO}_{2}(\mathrm{DPA})_{2}\right]_{-}^{3-} \mathrm{N}_{-} \mathrm{N}$

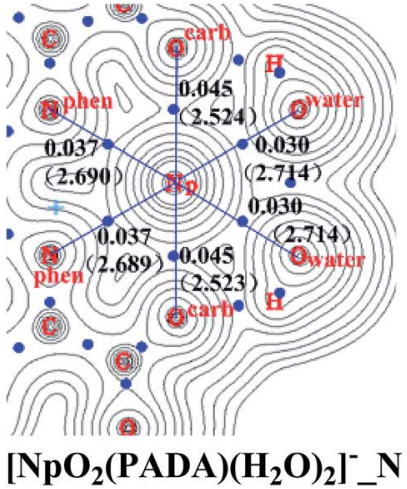

Fig. 3 Electron density $\rho_{\mathrm{b}}\left(\mathrm{e}^{-}\right.$bohr $\left.{ }^{-3}\right)$ and bond length $d\left(\AA \AA\right.$, in parenthesis) of $\mathrm{NpO}_{2}{ }^{+}$complexes from calculations in aqueous phase. 
feature. For these dative bonds, the electronic density $\rho_{\mathrm{b}}$ is close to $0, \nabla^{2} \rho_{\mathrm{b}}$ is positive, and $H_{\mathrm{b}} \approx 0$, indicating a depleted nature.

The $\delta(A, B)$ and $\varepsilon$ provides consistent results for the nature of the $\mathrm{Np}-\mathrm{O}^{\mathrm{yl}}$ and the coordination bonds. In the bare neptunyl ion, the delocalization index $(\delta(A, B))$ and the bond ellipticity $(\varepsilon)$ were calculated to be 2.970 and 0.002 in the gas phase and 2.860 and 0.000 in the aqueous phase, respectively, which suggests a triple bond feature for the $\mathrm{Np}-\mathrm{O}^{\mathrm{yl}}$ bond and is consistent with previous work. ${ }^{31}$ The explicit consideration of water ligands in the first coordination shell of neptunyl $\left(\left[\mathrm{NpO}_{2}\left(\mathrm{H}_{2} \mathrm{O}\right)_{5}\right]^{+}, \mathbf{N 1}\right)$ caused a marginal decrease of $\delta(A, B)$ of $\mathrm{Np}-\mathrm{O}^{\mathrm{yl}}$ bonds of about 0.04 , suggesting a weakening of the $\mathrm{Np}-\mathrm{O}^{\mathrm{yl}}$, while this does not change its triple bond feature.

Upon its coordination with the organic ligands studied here, the $\delta\left(\mathrm{Np}, \mathrm{O}^{\mathrm{yl}}\right)$ decreases further by $0.01-0.04$ with a slight increase of the bond ellipticity $(\varepsilon)$, indicating a stronger perturbation of the organic ligands to the bond nature of $\mathrm{Np}-\mathrm{O}^{\mathrm{yl}}$ than the water ligands.

For the dative bonds of the complexes, i.e. $\mathrm{Np}-\mathrm{N}^{\mathrm{py}}, \mathrm{Np}-\mathrm{O}^{\text {carb }}$, and $\mathrm{Np}-\mathrm{O}^{\text {water }}$, the delocalization indices $(\delta(A, B))$ are in the range of $0.62-1.08$, and the bond ellipticity $(\varepsilon)$ values are in the range of $0.06-0.39$. Among the dative bonds, the $\mathrm{Np}-\mathrm{O}^{\text {carb }}$ bonds appear with the largest $\delta(A, B)$, and for the same coordination mode, the more ligands coordinated to $\mathrm{Np}$, the lower the $\delta(A, B)$ value (P1C and P1N vs. P2CN and P2NN vs. P3CNN and P3NNN, D1N vs. D2CN and D2NN, H1W1 vs. H1W2), indicating the saturation in the coordination of neptunyl and the competition of the ligands in interacting with neptunyl.

In Fig. 2, the distance and the $\rho_{\mathrm{b}}$ at BCP of $\mathrm{Np}-\mathrm{O}^{\mathrm{yl}}$ bond as a function of the type of ligand are plotted. As seen in Fig. 2, the bond length $d$ increase from $1.781 \AA$ Å to $1.823 \AA$, and the electron density $\rho_{\mathrm{b}}$ decrease from $0.294 \mathrm{e} \mathrm{bohr}^{-3}$ to $0.266 \mathrm{e} \mathrm{bohr}^{-3}$ at BCP of Np- $\mathrm{O}^{\mathrm{yl}}$ bond in $\mathrm{NpO}_{2} \mathrm{~L}_{n}\left(\mathrm{~L}=\mathrm{H}_{2} \mathrm{O}, \mathrm{PA}^{-}, \mathrm{DPA}^{2-}, \mathrm{PADA}^{2-}\right.$, $n(\mathrm{~L})=0,1)$ complexes in the aqueous phase, which indicates enhanced perturbation on the strength of $\mathrm{Np}-\mathrm{O}^{\mathrm{yl}}$ bond by the coordination of the organic ligands in the complexes with the same stoichiometric ratio $\mathrm{M}: \mathrm{L}=1: 1$, suggesting the binding affinity of neptunyl to the ligands decreases in the order: $\mathrm{PADA}^{2-}>\mathrm{DPA}^{2-}>\mathrm{PA}^{-}>\mathrm{H}_{2} \mathrm{O}$. The higher presence of the ligands brings more perturbation to the $\mathrm{Np}-\mathrm{O}^{\mathrm{yl}}$ bond.

In Fig. 3, the electron density in the equatorial plane transverse to the axis of neptunyl through $\mathrm{Np}$ is shown for the representative complexes complexes $\left(\mathrm{NpO}_{2} \mathrm{~L}_{n}\left(\mathrm{H}_{2} \mathrm{O}\right)_{m}\right)^{j}\left(\mathrm{~L}=\mathrm{PA}^{-}\right.$, $\mathrm{DPA}^{2-}$, and PADA $\left.{ }^{2-}, n=0-3, m=0-3,5, j=1+, 0,1-, 2-, 3-\right)$, and the bond lengths of the dative bonds in the plane are also given. The data of $\mathrm{Np}-\mathrm{O}^{\mathrm{yl}}$ for the bare neptunyl are also shown. In these complexes, the $\rho_{\mathrm{b}}$ of $\mathrm{Np}-\mathrm{N}$ bond is always smaller than that of $\mathrm{Np}-\mathrm{O}^{\text {carb }}$, suggesting a larger accumulation of electron density of the latter than the former. This is consistent with their delocalization indices collected in Table 3.

\section{Charge transfer in the complexes}

The charge decomposition analysis (CDA) proposed by Dapprich and Frenking, ${ }^{57,58}$ and the extended charge decomposition analysis (ECDA) by Gorelsky ${ }^{59,60}$ are used to calculate charge transfer between neptunyl and the ligands upon the ligand exchange. In CDA, the overall reorganization of electronic density is calculated which includes both the contributions of charge transfer (CT) and electronic polarization (PL). These are separated in ECDA, and the transferred charge can be directly obtained as $\mathrm{CT}(\mathrm{A} \rightarrow \mathrm{B})-\mathrm{CT}(\mathrm{B} \rightarrow \mathrm{A})=[\mathrm{PL}(\mathrm{A})+\mathrm{CT}(\mathrm{A} \rightarrow \mathrm{B})]-$ $[\mathrm{PL}(\mathrm{A})+\mathrm{CT}(\mathrm{B} \rightarrow \mathrm{A})]$.

Here we consider the net charge transfer from the ligands to neptunyl in selected complexes by the CDA and ECDA methods at the B3LYP level, and the data are tabulated in Table 4. For $\mathrm{Np}: \mathrm{L}=1: 1$ type complexes, the net charge transfer from the ligands to neptunyl decreases in the order of $\mathrm{PADA}^{2-}>\mathrm{DPA}^{2-}>$ $\mathrm{PA}^{-}>\mathrm{H}_{2} \mathrm{O}$ (in the range of $0.610-0.648,0.594-0.615,0.585-$ $0.591,0.573$, and $0.900-0.999,0.880-0.941,0.871-0.878,0.816$, obtained by CDA and ECDA, respectively). This coincides the sequence of the relative stabilities, which suggests that the ligand-to-metal-charge-transfer (LMCT) plays an important role in the higher binding affinity of $\mathrm{PADA}^{2-}$ and $\mathrm{DPA}^{2-}$ than that of $\mathrm{PA}^{-}$and $\mathrm{H}_{2} \mathrm{O}$.

We note that the charge transfer is also correlated to the coordination mode. According to ECDA results, for each pair of isomers, e.g. P2CN vs. P2NN, P3CNN vs. P3NNN, and D2CN vs. D2CN, the co-presence of the $\mathrm{C}$ and the $\_\mathrm{N}$ coordination modes causes more charge transfer from ligands to neptunyl. In the complexes with a single organic ligands, i.e. P1C vs. P1N, D1C vs. D1N, and H1C vs. H1N, the latter appears with more charge transfer than the former. These results suggest that the combined hard-soft strategy, i.e. the harder $\mathrm{O}^{\text {carb }}$ and the softer $\mathrm{N}^{\mathrm{py}}$, favors to stabilize the complexes with stronger electrostatic interaction between neptunyl and the ligands compared to the other coordination modes. This offers theoretical supports on the combined hard-soft strategy to develop extractants with higher selectivity towards the actinides. ${ }^{19,61,62}$

\section{Molecular orbital (MO) and NAO analysis}

The natural atomic orbital (NAO) ${ }^{63}$ was analyzed to understand the bonding of $\mathrm{NpO}_{2}{ }^{+}$with ligands, and the representative $\alpha$-spin frontier orbitals of P1C, P1N, D1N and H1W1 are shown

Table 4 Charge transfer $\left(\mathrm{e}^{-}\right)$in the complexes from the ligands to $\mathrm{NpO}_{2}{ }^{+}$by the CDA and ECDA methods calculated at the B3LYP level

\begin{tabular}{|c|c|c|c|}
\hline Complexes & Charge transfer & CDA & ECDA \\
\hline$(\mathbf{N 1})\left[\mathrm{NpO}_{2}\left(\mathrm{H}_{2} \mathrm{O}\right)_{5}\right]^{+}$ & $5 \mathrm{H}_{2} \mathrm{O} \rightarrow \mathrm{NpO}_{2}^{+}$ & 0.5734 & 0.8157 \\
\hline$(\mathbf{P 1 C})\left[\mathrm{NpO}_{2}(\mathrm{PA})\left(\mathrm{H}_{2} \mathrm{O}\right)_{3}\right]_{-} \mathrm{C}$ & $\mathrm{L}+3 \mathrm{H}_{2} \mathrm{O} \rightarrow \mathrm{NpO}_{2}^{+}$ & 0.5908 & 0.8713 \\
\hline$(\mathbf{P 1 N})\left[\mathrm{NpO}_{2}(\mathrm{PA})\left(\mathrm{H}_{2} \mathrm{O}\right)_{3}\right]_{-} \mathrm{N}$ & $\mathrm{L}+3 \mathrm{H}_{2} \mathrm{O} \rightarrow \mathrm{NpO}_{2}^{+}$ & 0.5852 & 0.8780 \\
\hline$(\mathbf{P} 2 \mathrm{CN})\left[\mathrm{NpO}_{2}(\mathrm{PA})_{2}\left(\mathrm{H}_{2} \mathrm{O}\right)\right]^{-}{ }_{-} \mathrm{C} \_\mathrm{N}$ & $2 \mathrm{~L}+\mathrm{H}_{2} \mathrm{O} \rightarrow \mathrm{NpO}_{2}^{+}$ & 0.6542 & 0.9885 \\
\hline$(\mathbf{P} 2 \mathrm{NN})\left[\mathrm{NpO}_{2}(\mathrm{PA})_{2}\left(\mathrm{H}_{2} \mathrm{O}\right)\right]^{-}{ }_{-} \mathrm{N} \_\mathrm{N}$ & $2 \mathrm{~L}+\mathrm{H}_{2} \mathrm{O} \rightarrow \mathrm{NpO}_{2}^{+}$ & 0.6315 & 0.9681 \\
\hline$(\mathbf{P} 3 \mathrm{CNN})\left[\mathrm{NpO}_{2}(\mathrm{PA})_{3}\right]^{2-}{ }_{-} \mathrm{C} \_\mathrm{N} \_\mathrm{N}$ & $3 \mathrm{~L} \rightarrow \mathrm{NpO}_{2}^{+}$ & 0.7408 & 1.1201 \\
\hline$(\mathbf{P} 3 \mathrm{NNN})\left[\mathrm{NpO}_{2}(\mathrm{PA})_{3}\right]^{2-}$-N_N_N & $3 \mathrm{~L} \rightarrow \mathrm{NpO}_{2}^{+}$ & 0.6970 & 1.0751 \\
\hline$(\mathrm{D} 1 \mathrm{C})\left[\mathrm{NpO}_{2}(\mathrm{DPA})\left(\mathrm{H}_{2} \mathrm{O}\right)_{3}\right]^{-}{ }_{-} \mathrm{C}$ & $\mathrm{L}+3 \mathrm{H}_{2} \mathrm{O} \rightarrow \mathrm{NpO}_{2}^{+}$ & 0.5942 & 0.8799 \\
\hline$(\mathrm{D} 1 \mathrm{~N})\left[\mathrm{NpO}_{2}(\mathrm{DPA})\left(\mathrm{H}_{2} \mathrm{O}\right)_{2}\right]^{-}{ }_{-} \mathrm{N}$ & $\mathrm{L}+2 \mathrm{H}_{2} \mathrm{O} \rightarrow \mathrm{NpO}_{2}^{+}$ & 0.6152 & 0.9411 \\
\hline (D2CN) $\left[\mathrm{NpO}_{2}(\mathrm{DPA})_{2}\right]^{3-}{ }_{-} \mathrm{C} \_\mathrm{N}$ & $2 \mathrm{~L} \rightarrow \mathrm{NpO}_{2}^{+}$ & 0.7429 & 1.1310 \\
\hline$(\mathbf{D} 2 \mathrm{NN})\left[\mathrm{NpO}_{2}(\mathrm{DPA})_{2}\right]^{3-}{ }_{-} \mathrm{N} \_\mathrm{N}$ & $2 \mathrm{~L} \rightarrow \mathrm{NpO}_{2}^{+}$ & 0.7897 & 1.2131 \\
\hline$(\mathrm{H1C})\left[\mathrm{NpO}_{2}(\mathrm{PADA})\left(\mathrm{H}_{2} \mathrm{O}\right)_{3}\right]^{-}{ }_{-} \mathrm{C}$ & $\mathrm{L}+3 \mathrm{H}_{2} \mathrm{O} \rightarrow \mathrm{NpO}_{2}^{+}$ & 0.6097 & 0.8996 \\
\hline (H1W1) $\left[\mathrm{NpO}_{2}(\mathrm{PADA})\left(\mathrm{H}_{2} \mathrm{O}\right)\right]^{-}{ }_{-} \mathrm{N}$ & $\mathrm{L}+\mathrm{H}_{2} \mathrm{O} \rightarrow \mathrm{NpO}_{2}^{+}$ & 0.6211 & 0.9770 \\
\hline$(\mathbf{H} 1 W 2)\left[\mathrm{NpO}_{2}(\mathrm{PADA})\left(\mathrm{H}_{2} \mathrm{O}\right)_{2}\right]^{-}{ }_{-} \mathrm{N}$ & $\mathrm{L}+2 \mathrm{H}_{2} \mathrm{O} \rightarrow \mathrm{NpO}_{2}^{+}$ & 0.6483 & 0.9987 \\
\hline
\end{tabular}




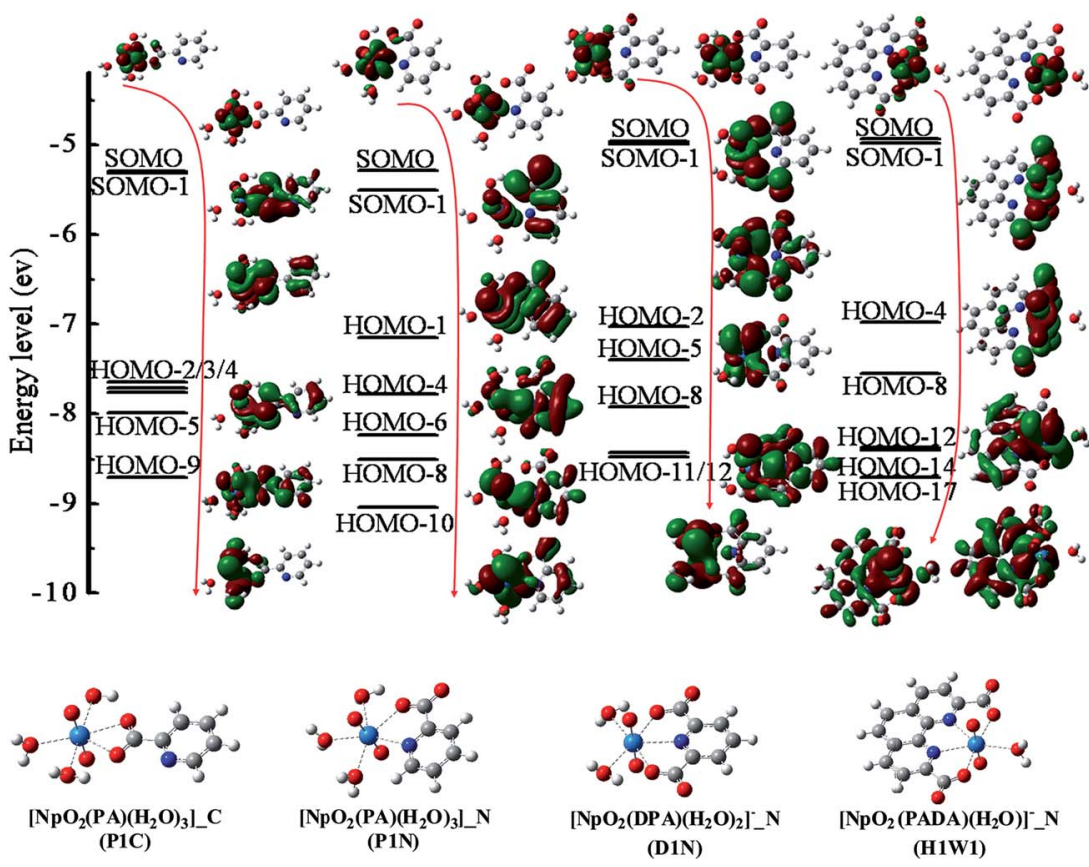

Fig. 4 Representative $\alpha$-spin frontier orbitals of $\mathrm{NpO}_{2}{ }^{+}$complexes. The isosurface value of $\mathrm{MO}$ is 0.02 a.u.

in Fig. 4 and their compositions are tabulated in Table 5. These MOs are mainly contributed by the $2 \mathrm{p}$ atomic orbital of the $\mathrm{O} / \mathrm{N}$ atoms and $5 \mathrm{f}$ or $6 \mathrm{~d}$ atomic orbital of neptunium.
As shown in Fig. 4, for all of the four complexes, the two singly occupied molecular orbitals (SOMO) are contributed by the $\mathrm{Np}$ and the $\mathrm{O}^{\mathrm{yl}}$ atoms, which is consistent with the observations that the unpaired electrons are localized within the

Table 5 Representative orbitals ( $\alpha$-spin MOs) with Np contributions (\%) higher than $5 \%$ at the B3LYP level

\begin{tabular}{llllll}
\hline P1C & HOMO-2 & HOMO-3 & HOMO-4 & HOMO-5 \\
\hline $\mathrm{Np}$ & 4.1 & 30.2 & 23.0 & 9.2 & HOMO-9 \\
$5 \mathrm{f} / 6 \mathrm{~d}$ & $5 \mathrm{f}_{y\left(3 x^{2}-y^{2}\right)}: 1.6$ & $5 \mathrm{f}_{z^{3}}: 24.4$ & $5 \mathrm{f}_{z^{z}}: 18.1,5 \mathrm{f}_{x y z}: 1.3$ & $5 \mathrm{f}_{x z^{2}}: 3.9$ & 9.3 \\
$\mathrm{O}^{1 \mathrm{~A}} / \mathrm{O}^{1 \mathrm{~B}}$ & $\mathrm{O}^{1 \mathrm{~B}}: 7.0\left(2 \mathrm{p}_{x}\right), 17.7\left(2 \mathrm{p}_{y}\right)$ & $\mathrm{O}^{1 \mathrm{~B}}: 13.9\left(2 \mathrm{p}_{z}\right)$ & $\mathrm{O}^{1 \mathrm{~B}}: 22.3\left(2 \mathrm{p}_{z}\right)$ & $\mathrm{O}^{1 \mathrm{~B}}: 29.3\left(2 \mathrm{p}_{x}\right), 2.7\left(2 \mathrm{p}_{y}\right)$ & $\mathrm{O}_{y z}: 8.8$ \\
& $\mathrm{O}^{1 \mathrm{~A}}: 30.1\left(2 \mathrm{p}_{x}\right), 25.8\left(2 \mathrm{p}_{y}\right)$ & $\mathrm{O}^{1 \mathrm{~A}}: 19.7\left(2 \mathrm{p}_{z}\right)$ & $\mathrm{O}^{1 \mathrm{~A}}: 25.7\left(2 \mathrm{p}_{z}\right)$ & $\mathrm{O}^{1 \mathrm{~A}}: 11.9\left(2 \mathrm{p}_{x}\right)$ & $\mathrm{O}^{1 \mathrm{~A}}: 1.9\left(2 \mathrm{p}_{z}\right)$ \\
\hline
\end{tabular}

\begin{tabular}{llllll}
\hline P1N & HOMO-1 & HOMO-4 & HOMO-6 & HOMO-8 \\
\hline $\mathrm{Np}$ & 6.5 & 39.9 & 11.0 & 21.4 & HOMO-10 \\
$5 \mathrm{f} / 6 \mathrm{~d}$ & $5 \mathrm{f}_{z^{3}}: 4.5$ & $5 \mathrm{f}_{z^{3}}: 32.8$ & $5 \mathrm{f}_{z^{3}}: 1.0,5 \mathrm{f}_{x z^{2}}: 2.9,5 \mathrm{f}_{y z^{2}}: 1.4$ & $5 \mathrm{f}_{x z^{2}}: 15.6,5 \mathrm{f}_{y z^{2}}: 3.3$ & 13.9 \\
$\mathrm{~N}^{1} / \mathrm{O}^{1 \mathrm{~A}}$ & $\mathrm{O}^{1 \mathrm{~A}}: 32.2\left(2 \mathrm{p}_{z}\right)$ & $\mathrm{N}^{1}: 2.4\left(2 \mathrm{p}_{z}\right)$, & $\mathrm{N}^{1}: 26.4\left(2 \mathrm{p}_{x}\right), 4.6\left(2 \mathrm{p}_{z}\right), \mathrm{O}^{1 \mathrm{~A}}: 1.4\left(2 \mathrm{p}_{y}\right)$ & $\mathrm{N}^{1}: 1.6(2 \mathrm{~s}), 16.2\left(2 \mathrm{p}_{x}\right)$ & $\mathrm{N}^{1}: 1.2\left(2 \mathrm{p}_{z}\right)$ \\
& & $\mathrm{O}^{1 \mathrm{~A}}: 9.6\left(2 \mathrm{p}_{z}\right)$ & & & \\
\end{tabular}

\begin{tabular}{|c|c|c|c|c|c|}
\hline D1N & HOMO-2 & HOMO-5 & HOMO-8 & HOMO-11 & HOMO-12 \\
\hline $\mathrm{Np}$ & 18.8 & 5.5 & 23.9 & 5.8 & 10.8 \\
\hline $5 f / 6 d$ & $5 f_{z^{3}}: 14.6$ & $5 \mathrm{f}_{y z^{2}}: 1.3,6 \mathrm{~d}_{x y}: 1.4$ & $5 f_{x z^{2}}: 21.2$ & $\begin{array}{l}5 \mathrm{f}_{x z^{2}}: 1.4,5 \mathrm{f}_{x\left(x^{2}-3 y^{2}\right)}: 1.3 \\
6 \mathrm{~d}_{x^{2} y^{2}}: 1.6\end{array}$ & $6 \mathrm{~d}_{y z}: 9.8$ \\
\hline $\mathrm{N}^{1} / \mathrm{O}^{2 \mathrm{~A}} / \mathrm{O}^{1 \mathrm{~A}}$ & $\begin{array}{l}\mathrm{O}^{2 \mathrm{~A}}: 16.2\left(2 \mathrm{p}_{z}\right) \\
\mathrm{O}^{1 \mathrm{~A}}: 16.2\left(2 \mathrm{p}_{z}\right)\end{array}$ & $\begin{array}{l}\mathrm{O}^{2 \mathrm{~A}}: 2.1\left(2 \mathrm{p}_{x}\right), 29.1\left(2 \mathrm{p}_{y}\right), \\
\mathrm{O}^{1 \mathrm{~A}}: 2.1\left(2 \mathrm{p}_{x}\right), 29.1\left(2 \mathrm{p}_{y}\right)\end{array}$ & $\begin{array}{l}\mathrm{N}^{1}: 1.2\left(2 \mathrm{p}_{x}\right), \mathrm{O}^{2 \mathrm{~A}}: 2.5\left(2 \mathrm{p}_{y}\right) \\
\mathrm{O}^{1 \mathrm{~A}}: 2.5\left(2 \mathrm{p}_{y}\right)\end{array}$ & $\begin{array}{l}\mathrm{N}^{1}: 3.5(2 \mathrm{~s}), 34.9\left(2 \mathrm{p}_{x}\right) \\
\mathrm{O}^{2 \mathrm{~A}}: 2.2\left(2 \mathrm{p}_{y}\right), \mathrm{O}^{1 \mathrm{~A}}: 2.2\left(2 \mathrm{p}_{y}\right)\end{array}$ & $\begin{array}{l}\mathrm{N}^{1}: 0.9\left(2 \mathrm{p}_{x}\right), \mathrm{O}^{2 \mathrm{~A}}: 1.8\left(2 \mathrm{p}_{z}\right) \\
\mathrm{O}^{1 \mathrm{~A}}: 1.8\left(2 \mathrm{p}_{z}\right)\end{array}$ \\
\hline
\end{tabular}

\begin{tabular}{|c|c|c|c|c|c|}
\hline H1W1 & HOMO-4 & HOMO-8 & HOMO-12 & HOMO-14 & HOMO-17 \\
\hline $\mathrm{Np}$ & 19.4 & 36.2 & 6.9 & 6.55 & 6.3 \\
\hline $\begin{array}{l}5 f / 6 d \\
N^{1} / N^{2} / O^{2 A} / O^{1 A}\end{array}$ & $\begin{array}{l}5 \mathrm{f}_{z^{3}}: 13.5,5 \mathrm{f}_{z\left(x^{2}-y^{2}\right)}: 2.5 \\
\mathrm{O}^{2 \mathrm{~A}}: 15.9\left(2 \mathrm{p}_{z}\right) \\
\mathrm{O}^{1 \mathrm{~A}}: 17.3\left(2 \mathrm{p}_{z}\right)\end{array}$ & $\begin{array}{l}5 f_{z^{3}}: 29.8 \\
\mathrm{O}^{2 \mathrm{~A}}: 6.3\left(2 \mathrm{p}_{z}\right) \\
\mathrm{O}^{1 \mathrm{~A}}: 6.5\left(2 \mathrm{p}_{z}\right)\end{array}$ & $\begin{array}{l}5 \mathrm{f}_{x z^{2}}: 1.6,6 \mathrm{~d}_{x z}: 2.7 \\
\mathrm{~N}^{2}: 5.7\left(2 \mathrm{p}_{x}\right), 4.8\left(2 \mathrm{p}_{y}\right) \\
\mathrm{N}^{1}: 4.4\left(2 \mathrm{p}_{x}\right), 2.5\left(2 \mathrm{p}_{y}\right)\end{array}$ & $\begin{array}{l}5 \mathrm{f}_{y\left(3 x^{2}-y^{2}\right)}: 2.0,6 \mathrm{~d}_{x y}: 2.3 \\
\mathrm{~N}^{2}: 13.3\left(2 \mathrm{p}_{x}\right), 6.1\left(2 \mathrm{p}_{y}\right) \\
2.2\left(2 \mathrm{p}_{z}\right), \mathrm{N}^{1}: 16.4\left(2 \mathrm{p}_{x}\right) \\
4.1\left(2 \mathrm{p}_{y}\right), 2.7\left(2 \mathrm{p}_{z}\right)\end{array}$ & $\begin{array}{l}6 \mathrm{~d}_{z^{2}}: 1.0 \\
\mathrm{~N}^{2}: 4.8\left(2 \mathrm{p}_{x}\right), 4.4\left(2 \mathrm{p}_{y}\right), \\
\mathrm{N}^{1}: 6.0\left(2 \mathrm{p}_{x}\right), 3.2\left(2 \mathrm{p}_{y}\right)\end{array}$ \\
\hline
\end{tabular}


neptunyl moiety indicated by the spin density distribution. For the orbitals that constituted from both the neptunyl and the ligands, it is shown that from P1C to P1N to D1N and H1W1, there is increasing orbital overlap from these fragments, suggesting stronger ionic feature in P1C while more covalency in the other complexes. This indicates that the excess stabilization brought by $\_\mathrm{N}$ coordination mode (P1N, D1N, and H1W1), compared to the _C mode (P1C), may be contributed by the enhanced covalent interaction between the neptunyl and the ligands.

As listed in Table 5, the compositions of the representative orbitals display localized feature, i.e. the major contribution comes from the $\mathrm{Np}$ and the ligand atoms coordinated to Np. For the complex P1C, some frontier MOs contains significant contributions from the two $\mathrm{O}^{\text {carb }}$ atoms of the same carboxylate group. It is conceivable that this perturbs the delocalization feature of electrons in the carboxylate group. In the other complexes, the $\mathrm{N}$ atoms and one $\mathrm{O}^{\text {carb }}$ atom of each carboxylate group have noticeable contributions. This avoids significant perturbation to the ligands and maintains the aromaticity of the hetero-rings and the local electronic feature of the carboxylate groups of the ligands.

\section{E. Comparison with the experimental work}

In Rao et al. 's work, ${ }^{25}$ the trends in the protonation constants of $\mathrm{H}_{2}$ PADA and related ligands and the thermodynamic data for
$\mathrm{Np}^{\mathrm{V}}$ complexes with three ligands were discussed. The first protonation constants of the ligands were observed to decrease in the order: $\mathrm{HPA}>\mathrm{H}_{2}$ DPA $>\mathrm{H}_{2}$ PADA. This trend was explained by the intramolecular hydrogen bonding between the carboxylate group and the nitrogen atom which became weaker along the series. Though the preparation of the crystals of the $\mathrm{Np}^{\mathrm{V}}$ / PADA $^{2-}$ complex was not successful, the spectrophotometric and calorimetric data undoubtedly indicated that the $1: 1$ complex formed in solution and appeared to be much stronger than complexes formed by the other two ligands. This is reasonable concerning the increase in denticity from HPA to $\mathrm{H}_{2}$ DPA and $\mathrm{H}_{2}$ PADA that stabilizes the $\mathrm{Np}^{\mathrm{V}}$ complexes: $\mathrm{PA}^{-}<$ $\mathrm{DPA}^{2-}<\mathrm{PADA}^{2-}$. Our calculations are consistent with the experimental observations on the variation of the stability constants of the complexes in view of the relative free energies of complexation, which are tabulated in Table 2.

The calculated entropic and enthalpic contributions are plotted in Fig. 5. For Np : $\mathrm{L}=1: 1$ type complexes, based on our calculations, their formation of relative Gibbs free energies decreased by the order: $\mathrm{PADA}^{2-}\left(-55.10 \mathrm{kcal} \mathrm{mol}^{-1}\right)>\mathrm{DPA}^{2-}$ $\left(-40.71 \mathrm{kcal} \mathrm{mol}^{-1}\right)>\mathrm{PA}^{-}\left(-20.75 \mathrm{kcal} \mathrm{mol}^{-1}\right)$ in the aqueous phase. This trend is consistent with the experimental data which report the free energy changes of $-15.99 \mathrm{kcal} \mathrm{mol}^{-1}$ for $\mathrm{PADA}^{2-},-11.85 \mathrm{kcal} \mathrm{mol}^{-1}$ for $\mathrm{DPA}^{2-}$, and $-4.90 \mathrm{kcal} \mathrm{mol}^{-1}$ for $\mathrm{PA}^{-}$. We note that there is substantial difference in the values between the calculated and the experimentally derived ones,
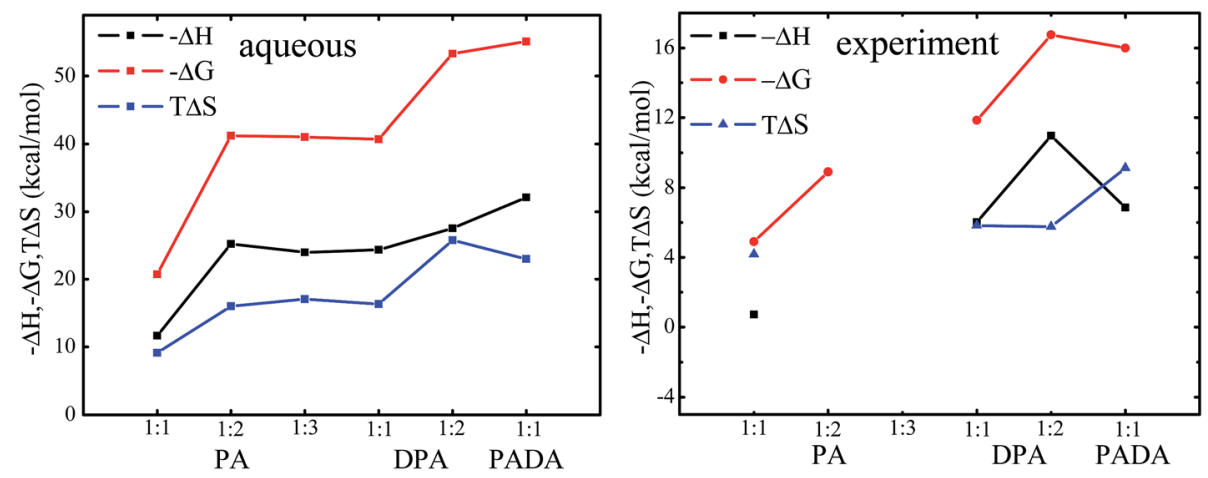

Fig. 5 Thermodynamic trends of $\mathrm{NpO}_{2}{ }^{+}$complexes from calculations in the aqueous phase (left) and from experiment (right).
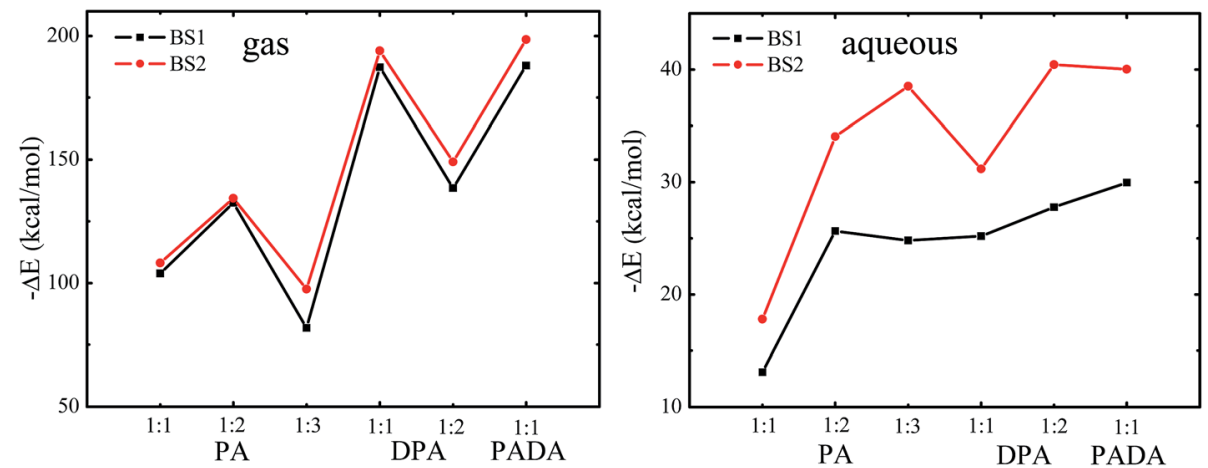

Fig. 6 The relative electronic energies of $\mathrm{NpO}_{2}{ }^{+}$complexes calculated using basis set BS1 and larger basis set BS2 in the gas phase and aqueous phase. 
which may be due to the treatment of the model systems in this work, e.g. the insufficient sampling of the model systems, the implicit treatment of solvent effect, and the omitting of the counterion effect. This makes it hard to make a direct comparison between them, and molecular dynamic simulations at first-principle level are needed which is beyond the scope of this work.

The energies were refined by using more sophisticated treatment (BS2) of the atoms where a larger basis set 6$311++\mathrm{G}(\mathrm{d}, \mathrm{p})$ was used for the atoms except for $\mathrm{Np}$, and the results were plotted in Fig. 6 . The data show that for the three ligands, when they form complexes with neptunyl with the same stoichiometric ratio, higher denticity brings more stabilization energy, i.e. the stability of the complexes decrease in the order of $\mathrm{PADA}^{2-}>\mathrm{DPA}^{2-}>\mathrm{PA}^{-}$. This trend is consistent with the data from the calculations at the B3LYP/BS1 level, and agrees with the reported experimental observations.

\section{Conclusions}

In the present work, we report a DFT study of the interactions between neptunyl ion $\left(\mathrm{NpO}_{2}^{+}\right)$and the deprotonated 1,10phenanthrolin-2,9-dicarboxylic acid anion $\left(\mathrm{PADA}^{2-}\right)$. Its analogs, the deprotonated picolinic acid anion $\left(\mathrm{PA}^{-}\right)$and dipicolinic acid anion $\left(\mathrm{DPA}^{2-}\right)$, were also investigated and compared. The geometries, thermodynamics of the complexation reactions, and the electronic structures of the complexes were analyzed to evaluate the coordination modes and stoichiometry ratio of neptunyl ion with ligands. The calculations indicate that the coordination of $\mathrm{NpO}_{2}{ }^{+}$to tetradentate chelators is more favorable than that to tridentate and bidentate ones, and the coordination ability of three deprotonated ligands follows the order: $\mathrm{PADA}^{2-}>\mathrm{DPA}^{2-}>\mathrm{PA}^{-}$.

The QTAIM analysis showed that the metal-ligand interactions have strong ionic feature. In addition to the QTAIM analysis, the charge decomposition analysis (CDA) and extended charge decomposition analysis (ECDA) were performed to quantify the charge donation and back-donation between the metal and ligand fragments in complexes. For $\mathrm{Np}: \mathrm{L}=1: 1$ type complexes, the net charge transfer from the ligands to neptunyl decreases in the order of $\mathrm{PADA}^{2-}>\mathrm{DPA}^{2-}>$ $\mathrm{PA}^{-}>\mathrm{H}_{2} \mathrm{O}$, which is in good agreement with the relative thermodynamic stabilities of the corresponding complexes. The natural atomic orbital (NAO) analysis revealed that the $5 \mathrm{f}$ orbitals of Np participated in the metal-ligand dative bond and contribute to its covalency.

In summary, our calculations show that the denticity of ligand and the combined hard-soft donor strategy work cooperatively in the coordination of $\mathrm{Np}$ with ligands, which should be taken into account in the rational design of new type of extractants for the separation of Np.

\section{Acknowledgements}

This work was financially supported by the National Natural Science Foundation of China to W. Chen (10676007), to Z. Chai (91026000) and to D. Wang (21473206, 91226105), which are gratefully acknowledged. The Special Program for Applied Research on Super Computation of the NSFC-Guangdong Joint Fund (the second phase), the National Supercomputing Center in Tianjin (NSCC-TJ), the Supercomputing Center of Chinese Academy of Sciences are acknowledged for providing computational grids.

\section{References}

1 J. Bruno and R. C. Ewing, Elements, 2006, 2, 343-349.

2 P. C. Burns, K. M. Deely and S. Skanthakumar, Radiochim. Acta, 2004, 92, 151-160.

3 P. A. Baisden and G. R. Choppin, Radiochemistry and Nuclear Chemistry, 2007, pp. 1-63.

4 E. Bondietti, Environmental migration of long-lived radionuclides, 1982, pp. 81-96.

5 W. Runde, S. D. Conradson, D. W. Efurd, N. Lu, C. E. VanPelt and C. D. Tait, Appl. Geochem., 2002, 17, 837-853.

6 K. Balasubramanian and Z. Cao, Inorg. Chem., 2007, 46, 10510-10519.

7 M. Garcia-Hernandez, C. Willnauer, S. Kruger, L. V. Moskaleva and N. Rosch, Inorg. Chem., 2006, 45, 1356-1366.

8 F. Gendron, D. Paez-Hernandez, F. P. Notter, B. Pritchard, H. Bolvin and J. Autschbach, Chem.-Eur. J., 2014, 20, 79948011.

9 X. Yang, Y. N. Liang, S. D. Ding, S. J. Li, Z. F. Chai and D. Q. Wang, Inorg. Chem., 2014, 53, 7848-7860.

10 D. Rios, P. X. Rutkowski, M. J. Van Stipdonk and J. K. Gibson, Inorg. Chem., 2011, 50, 4781-4790.

11 V. N. Serezhkin, M. A. Krivopalova and L. B. Serezhkina, Russ. J. Coord. Chem., 1998, 24, 59-66.

12 Z. Kolarik, U. Müllich and F. Gassner, Solvent Extr. Ion Exch., 1999, 17, 23-32.

13 Z. Kolarik, U. Mullich and F. Gassner, Solvent Extr. Ion Exch., 1999, 17, 1155-1170.

14 M. G. Drew, M. R. Foreman, C. Hill, M. J. Hudson and C. Madic, Inorg. Chem. Commun., 2005, 8, 239-241.

15 M. R. S. J. Foreman, M. J. Hudson, A. Geist, C. Madic and M. Weigl, Solvent Extr. Ion Exch., 2005, 23, 645-662.

16 A. Geist, C. Hill, G. Modolo, M. R. S. J. Foreman, M. Weigl, K. Gompper and M. J. Hudson, Solvent Extr. Ion Exch., 2006, 24, 463-483.

17 F. W. Lewis, L. M. Harwood, M. J. Hudson, M. G. Drew, V. r. Hubscher-Bruder, V. Videva, F. O. Arnaud-Neu, K. Stamberg and S. Vyas, Inorg. Chem., 2013, 52, 4993-5005.

18 F. W. Lewis, L. M. Harwood, M. J. Hudson, M. G. Drew, J. F. Desreux, G. Vidick, N. Bouslimani, G. Modolo, A. Wilden and M. Sypula, J. Am. Chem. Soc., 2011, 133, 13093-13102.

19 C. L. Xiao, C. Z. Wang, L. Y. Yuan, B. Li, H. He, S. Wang, Y. L. Zhao, Z. F. Chai and W. Q. Shi, Inorg. Chem., 2014, 53, 1712-1720.

20 G. Tian, J. Xu and L. Rao, Angew. Chem., Int. Ed., 2005, 44, 6200-6203.

21 G. Tian, L. Rao and A. Oliver, Chem. Commun., 2007, 41194121, DOI: 10.1039/B706825E. 
22 L. Rao and G. Tian, Symmetry, 2009, 2, 1-14.

23 G. Tian, L. Rao and S. J. Teat, Inorg. Chem., 2009, 48, 1015810164.

24 Y. Gong, H.-S. Hu, L. Rao, J. Li and J. K. Gibson, J. Phys. Chem. A, 2013, 117, 10544-10550.

25 Y. Yang, Z. Zhang, S. Luo and L. Rao, Eur. J. Inorg. Chem., 2014, 2014, 5561-5566.

26 S. A. Ansari, A. Bhattacharyya, Z. Zhang and L. Rao, Inorg. Chem., 2015, 54, 8693-8698.

27 S. A. Ansari, P. Pathak, P. K. Mohapatra and V. K. Manchanda, Chem. Rev., 2011, 112, 1751-1772.

28 J. M. Combes, C. J. Chisholm-Brause, G. E. Brown Jr, G. A. Parks, S. D. Conradson, P. G. Eller, I. R. Triay, D. E. Hobart and A. Miejer, Environ. Sci. Technol., 1992, 26, 376-382.

29 Y. Inoue and O. Tochiyama, Polyhedron, 1983, 2, 627-630.

30 Y.-N. Liang, X. Yang, S. Ding, S. Li, F. Wang, Z. Chai and D. Wang, New J. Chem., 2015, 39, 7716-7729.

31 J. Zeng, X. Yang, J. Liao, N. Liu, Y. Yang, Z. Chai and D. Wang, Phys. Chem. Chem. Phys., 2014, 16, 16536-16546.

32 A. D. Becke, Phys. Rev. A, 1988, 38, 3098.

33 C. Lee, W. Yang and R. G. Parr, Phys. Rev. B: Condens. Matter Mater. Phys., 1988, 37, 785.

34 R. Conte, A. Aspuru-Guzik and M. Ceotto, J. Phys. Chem. Lett., 2013, 4, 3407-3412.

35 M. J. Frisch, G. W. Trucks, H. B. Schlegel, G. E. Scuseria, M. A. Robb, J. R. Cheeseman, G. Scalmani, V. Barone, B. Mennucci, G. A. Petersson, H. Nakatsuji, M. Caricato, X. Li, H. P. Hratchian, A. F. Izmaylov, J. Bloino, G. Zheng, J. L. Sonnenberg, M. Hada, M. Ehara, K. Toyota, R. Fukuda, J. Hasegawa, M. Ishida, T. Nakajima, Y. Honda, O. Kitao, H. Nakai, T. Vreven, J. A. Montgomery Jr, J. E. Peralta, F. Ogliaro, M. Bearpark, J. J. Heyd, E. Brothers, K. N. Kudin, V. N. Staroverov, R. Kobayashi, J. Normand, K. Raghavachari, A. Rendell, J. C. Burant, S. S. Iyengar, J. Tomasi, M. Cossi, N. Rega, J. M. Millam, M. Klene, J. E. Knox, J. B. Cross, V. Bakken, C. Adamo, J. Jaramillo, R. Gomperts, R. E. Stratmann, O. Yazyev, A. J. Austin, R. Cammi, C. Pomelli, J. W. Ochterski, R. L. Martin, K. Morokuma, V. G. Zakrzewski, G. A. Voth, P. Salvador, J. J. Dannenberg, S. Dapprich, A. D. Daniels, O. Farkas, J. B. Foresman, J. V. Ortiz, J. Cioslowski and D. J. Fox, Gaussian 09, Revision C.1, Gaussian, Inc., Wallingford, CT, 2009.

36 P. L. Houston, R. Conte and J. M. Bowman, J. Phys. Chem. A, 2014, 118, 7758-7775.

37 P. L. Houston, R. Conte and J. M. Bowman, J. Phys. Chem. A, 2015, 119, 4695-4710.

38 S. Huzinaga, Comput. Phys. Rep., 1985, 2, 281-339.
39 C. Xie, J. Li, D. Xie and H. Guo, J. Chem. Phys., 2012, 137, 024308.

40 R. Conte, C. Qu and J. M. Bowman, J. Chem. Theory Comput., 2015, 11, 1631-1638.

41 Z. Homayoon, R. Conte, C. Qu and J. M. Bowman, J. Chem. Phys., 2015, 143, 084302.

42 X. Cao, M. Dolg and H. Stoll, J. Chem. Phys., 2003, 118, 487496.

43 X. Cao and M. Dolg, J. Mol. Struct.: THEOCHEM, 2004, 673, 203-209.

44 W. Küchle, M. Dolg, H. Stoll and H. Preuss, J. Chem. Phys., 1994, 100, 7535-7542.

45 M. Cossi, N. Rega, G. Scalmani and V. Barone, J. Comput. Chem., 2003, 24, 669-681.

46 J. Tomasi, B. Mennucci and R. Cammi, Chem. Rev., 2005, 105, 2999-3094.

47 R. Dennington, T. Keith and J. Millam, GaussView, Version 5 , Semichem Inc., Shawnee Mission, KS, 2009.

48 T. Lu and F. Chen, J. Comput. Chem., 2012, 33, 580-592.

49 R. F. Bader, J. Phys. Chem. A, 1998, 102, 7314-7323.

50 A. Becke, C. F. Matta and R. J. Boyd, The quantum theory of atoms in molecules: from solid state to DNA and drug design, John Wiley \& Sons, 2007.

51 M. J. Tassell and N. Kaltsoyannis, Dalton Trans., 2010, 39, 6719-6725.

52 M. W. Schmidt, K. K. Baldridge, J. A. Boatz, S. T. Elbert, M. S. Gordon, J. H. Jensen, S. Koseki, N. Matsunaga, K. A. Nguyen and S. Su, J. Comput. Chem., 1993, 14, 13471363.

53 R. Conte, B. Fu, E. Kamarchik and J. M. Bowman, J. Chem. Phys., 2013, 139, 044104.

54 L.-H. Lee, in Fundamentals of Adhesion, Springer, 1991, pp. 349-362.

55 R. G. Pearson, J. Am. Chem. Soc., 1963, 85, 3533-3539.

56 C. F. Matta and R. J. Boyd, The Quantum Theory of Atoms in Molecules: From Solid State to DNA and Drug Design, 2007.

57 S. Dapprich and G. Frenking, J. Phys. Chem., 1995, 99, 93529362.

58 G. Frenking and N. Fröhlich, Chem. Rev., 2000, 100, 717-774.

59 S. I. Gorelsky, S. Ghosh and E. I. Solomon, J. Am. Chem. Soc., 2006, 128, 278-290.

60 S. I. Gorelsky and E. I. Solomon, Theor. Chem. Acc., 2008, 119, 57-65.

61 D. Manna and T. K. Ghanty, Phys. Chem. Chem. Phys., 2012, 14, 11060-11069.

62 P. R. Zalupski, D. D. Ensor, C. L. Riddle and D. R. Peterman, Solvent Extr. Ion Exch., 2013, 31, 430-441.

63 J. Foster and F. Weinhold, J. Am. Chem. Soc., 1980, 102, 72117218. 